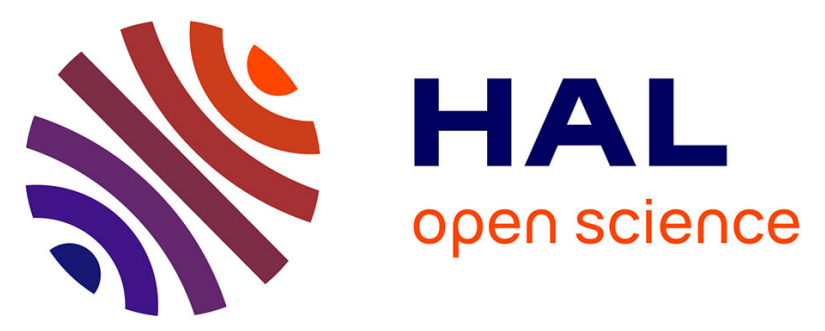

\title{
Clinical and biological features of B-cell neoplasms with CDK6 translocations: an association with a subgroup of splenic marginal zone lymphomas displaying frequent CD5 expression, prolymphocytic cells, and TP53 abnormalities
}

Baptiste Gailllard, Pascale Cornillet-lefebvre, Quoc-hung Le, Karim Maloum,

Mélanie Pannetier, Carinne Lecoq-lafon, Béatrice Grange, Ludovic

Jondreville, Lucienne Michaux, Nathalie Nadal, et al.

\section{To cite this version:}

Baptiste Gailllard, Pascale Cornillet-lefebvre, Quoc-hung Le, Karim Maloum, Mélanie Pannetier, et al.. Clinical and biological features of B-cell neoplasms with CDK6 translocations: an association with a subgroup of splenic marginal zone lymphomas displaying frequent CD5 expression, prolymphocytic cells, and TP53 abnormalities. British Journal of Haematology, 2020, 10.1111/bjh.17141 . hal03099358

\section{HAL Id: hal-03099358 \\ https: / hal.sorbonne-universite.fr/hal-03099358}

Submitted on 6 Jan 2021

HAL is a multi-disciplinary open access archive for the deposit and dissemination of scientific research documents, whether they are published or not. The documents may come from teaching and research institutions in France or abroad, or from public or private research centers.
L'archive ouverte pluridisciplinaire HAL, est destinée au dépôt et à la diffusion de documents scientifiques de niveau recherche, publiés ou non, émanant des établissements d'enseignement et de recherche français ou étrangers, des laboratoires publics ou privés. 
Clinical and biological features of B-cell neoplasms with CDK6 translocations: an association with a subgroup of splenic marginal zone lymphomas displaying frequent CD5 expression, prolymphocytic cells, and TP53 abnormalities.

B Gailllard ${ }^{1}$, P Cornillet-Lefebvre ${ }^{1}$, QH Le ${ }^{2}$, K Maloum $^{3}$, M Pannetier ${ }^{4}$, C Lecoq-Lafon ${ }^{1}$, B Grange ${ }^{5}$, L Jondreville ${ }^{6}$, L Michaux ${ }^{7}$ N Nadal $^{8}$, A Ittel ${ }^{9}$, I Luquet $^{10}$, S Struski ${ }^{10}$, C Lefebvre $^{11}$, JB Gaillard ${ }^{12}$, M LafagePochitaloff $^{13}, \mathrm{E}$ Balducci ${ }^{14}$, D Penther ${ }^{15}, \mathrm{C}$ Barin $^{16}, \mathrm{MA}$ Collonge-Rame $^{17}, \mathrm{M}$ Jimenez-Poquet $^{18}$, S Richebourg $^{19}$, P Lemaire ${ }^{20}$, S Defasque ${ }^{21}$, I Radford-Weiss ${ }^{22}$, A Bidet $^{23}$, SA Susin ${ }^{6,24}$, F Nguyen-Khac ${ }^{3,6,24}$, E Chapiro ${ }^{3,6,24}$, on behalf of the Groupe Francophone de Cytogénétique Hématologique.

1 Laboratoire d'Hématologie, Hôpital Robert Debré, Reims, France

2 Service d'Hématologie Clinique, Hôpital Robert Debré, Reims, France

3 Service d'Hématologie biologique, Hôpital Pitié-Salpêtrière, APHP, Paris, France

4 Laboratoire d'Hématologie, Centre Hospitalo-Universitaire, Rennes, France

5 Service d'Hématologie Biologique, Hospices Civils de Lyon, Lyon, France

6 Centre de Recherche des Cordeliers, INSERM UMRS_1138, Cell Death and Drug Resistance in

Lymphoproliferative Disorders Team, Paris, France

7 Center for Human Genetics, University Hospitals Leuven, Leuven, Belgium

8 Service de génétique chromosomique et moléculaire, CHU Dijon, France

9 Laboratoire de Cytogénétique, CHU de Strasbourg, Strasbourg, France

10 Laboratoire d'Hématologie, Institut Universitaire du Cancer de Toulouse, Toulouse, France

11 Laboratoire de Cytogénétique Onco-Hématologique, CHU Grenoble, France

12 Unité de Génétique Chromosomique, CHU Montpellier, France

13 Laboratoire de Cytogénétique Onco-Hématologique, Hôpital de la Timone, AP-HM, Aix-Marseille Université,

France

14 Laboratoire d'Hématologie, Hôpital Paul Brousse, APHP, Villejuif, France

15 Laboratoire de Génétique Oncologique, CLCC Henri Becquerel \& INSERM U1245, Rouen, France

16 Laboratoire de Cytogénétique hématologique, Service de Génétique, CHRU Bretonneau, Tours, France

17 Cytogénétique et Génétique Moléculaire, CHU Besançon, Besançon, France

18 Service de Génétique, Laboratoire Laborizon Centre- ABO, Chambray les Tours, France

19 Laboratoire de Cytogénétique Onco-Hématologique, CHU de Québec - Université Laval, Québec, Canada

20 Laboratoire d'Hématologie, Hôpital Saint-Louis, APHP, Paris, France

21 Secteur cytogénétique hématologique, Laboratoire CERBA, Saint-Ouen I'Aumône, France

22 Laboratoire de Cytogénétique, Hôpital Necker - Enfants Malades, APHP, Paris, France

23 Laboratoire d'Hématologie, CHU Bordeaux-Haut Lévêque, France

24 Sorbonne Université, Paris, France

Corresponding author: Elise Chapiro, elise.chapiro@aphp.fr

Service d'Hématologie Biologique, Bâtiment Pharmacie, 3e étage,

Pitié-Salpêtrière/Charles Foix University Hospital

83 Bd de l'Hôpital, F-75013 Paris, France

Tel.: +33-142-162-451; fax: +33-142-162-453

Short-title: Mature B-cell neoplasms with CDK6 translocations 


\section{SUMMARY}

A translocation involving the CDK6 gene $[\mathrm{t}(C D K 6)]$ is a rare but recurrent abnormality in B-cell neoplasms. To further characterize this aberration, we studied 57 cases - the largest series reported to date. FISH analysis confirmed the involvement of CDK6 in all cases, including $t(2 ; 7)(p 11 ; q 21)$ IGK/CDK6 ( $\mathrm{n}=51), \mathrm{t}(7 ; 14)(\mathrm{q} 21 ; \mathrm{q} 32)$ CDK6/IGH $(\mathrm{n}=2)$ and the previously undescribed $\mathrm{t}(7 ; 14)(\mathrm{q} 21 ; \mathrm{q} 11)$ CDK6/TRA-TRD $(\mathrm{n}=4)$. Ten patients were diagnosed with chronic lymphocytic leukemia, monoclonal B-cell lymphocytosis or small lymphocytic lymphoma, and 47 had small B-cell lymphoma (SmBL) including 36 cases of marginal zone lymphoma (MZL: 34 splenic MZLs, 1 nodal MZL and 1 bronchusassociated lymphoid tissue lymphoma). Eighteen of the 26 cytologically reviewed cases of MZL (69\%) had an atypical aspect with prolymphocytic cells. Among the $47 \mathrm{MZL} / \mathrm{SmBL}$ patients, CD5 expression was found in 26 (55\%) and the TP53 deletion in 22 (47\%). The TP53 gene was mutated in 10/30 (33\%); the 7q deletion was detected in only one case, and no NOTCH2 mutations were found. IGHV locus sequencing revealed that none harbored an IGHV1-02*04 gene. Overall survival was $82 \%$ at 10 years and not influenced by TP53 aberration. Our findings suggest that most $\mathrm{t}(C D K 6)+$ neoplasms correspond to a particular subgroup of indolent marginal zone B-cell lymphomas with distinctive features.

Key-words: CDK6, marginal zone lymphoma, TP53, prolymphocytic cell, CD5 


\section{INTRODUCTION}

A translocation involving the CDK6 gene is a rare but recurrent abnormality in mature B-cell neoplasms. Three different translocations have been described: $t(2 ; 7)(p 11 ; q 21)$ (the most frequent), $\mathrm{t}(7 ; 14)(q 21 ; \mathrm{q} 32)$ and $\mathrm{t}(7 ; 22)(\mathrm{q} 21 ; q 11)$, leading to juxtaposition of the CDK6 gene with the IGK, IGH or IGL locus, respectively, and thus CDK6 overexpression.

The $t(2 ; 7)$ was first reported by Vahdati et al. in 1983 in a patient with chronic lymphocytic leukemia (CLL) (Vahdati, et al 1983) and by Oscier et al. in 1993 in two cases of splenic lymphoma with villous lymphocytes (Oscier, et al 1993). Since then, about 40 cases of $t(2 ; 7)$ and its variants have been documented in patients with different diagnoses: splenic marginal zone lymphoma (SMZL) (Baro, et al 2008, Corcoran, et al 1999, Douet-Guilbert, et al 2014, Remstein, et al 2008, Salido, et al 2010, Xochelli, et al 2014), CLL (Cavazzini, et al 2008, Douet-Guilbert, et al 2014, Fink, et al 2006, Hayette, et al 2003), high-grade and low-grade B-cell lymphoma not otherwise specified (Chen, et al 2009), and monoclonal B-cell lymphocytosis (MBL) (Parker, et al 2011).

Given the rarity of $C D K 6$ translocations [ $\mathrm{t}(C D K 6)]$, the few studies published to date featured small numbers of patients. Hence, the associated clinical and biological features, genomic aberrations, and prognostic implications of this rare abnormality have not been fully characterized. Here, we describe the clinical, cytogenetic, and molecular features of 57 cases of B-cell neoplasms harboring a t(CDK6)the largest such series reported to date.

\section{METHODS}

\section{Patient selection}

Databases from 18 French, Belgian and Canadian institutions (covering the period from 2000 and 2017) were retrospectively screened for patients with a mature B-cell neoplasm harboring a $\mathrm{t}(2 ; 7)(\mathrm{p} 11 ; \mathrm{q} 21)$ or variants involving the CDK6 gene. The patients' characteristics at diagnosis were recorded when available. If possible, the immunophenotype was scored according to Matutes et al. (Matutes and Catovsky 1994) or Moreau et al. (Moreau, et al 1997). Cytogenetic and molecular analyses were performed at diagnosis for 38 patients, during follow-up and before treatment for 16 (median time between diagnosis and sampling: 28.5 months), and at relapse for 3 . The study was performed in accordance with the Declaration of Helsinki, and was approved by the local investigational review board (CPP Ile-de-France VI, Paris, France) on May 21 ${ }^{\text {th }}, 2014$. 
Karyotyping and FISH analysis

Standard chromosome banding analyses were used to obtain R-or G-banded chromosomes from peripheral blood $(n=44)$, bone marrow $(B M)(n=12)$ or lung biopsy $(n=1)$ samples. Karyotypes $(K)$ were reviewed by the members of the French-speaking Group for Cytogenetic Hematology (Groupe Francophone de Cytogénétique Hématologique) and classified according to the International System for Human Cytogenetic Nomenclature 2016. Complex K (CK) and high-complex K (HCK) were defined as the presence of at least three or at least five numerical or structural chromosomal abnormalities, respectively. FISH was performed according to standard procedures. The specific probes used were as follows: IGK (2p11) break-apart (Dako, Santa Clara, CA, and/or Cytocell, Cambridge, UK, or homegrown bacterial artificial chromosome (BAC) clones RP11-316G9, RP11-526L16 and RP11-1021F11 (Martin-Subero, et al 2002)), IGH (14q32) break-apart (Abbott Molecular, Des Plaines, IL), TRA/TRD (14q11) break-apart (Cytocell), ATM (11q22), TP53 (17p13), D13S319 (13q14), centromere of chromosome 12 (MetaSystems Probes, Altlussheim, Germany), BCL2 (18q21) break-apart and BCL6 (3q27) break-apart (Dako). A break-apart probe for CDK6 rearrangements was built using homegrown BAC clones RP11-246N14 and RP11-90H9. Extraction, labeling, and hybridization were performed as described previously (Cosson, et al 2014).

\section{Diagnoses and cytological assessments}

Of the 57 patients included in the study, 10 were initially diagnosed as having CLL $(n=6)$, high-count CLL-like MBL $(n=2)$ and SLL $(n=2)$, according to the World Health Organization criteria (Swerdlow, et al 2017). A cytology review was performed in six of the 10 cases. Among the 47 other patients, 3 were classified as B-cell prolymphocytic leukemia (B-PLL) and 44 were considered as low grade lymphomas, excluding mantle cell lymphoma and follicular lymphoma. Most of these 44 cases were classified as MZL, including 4 with a histological confirmation on a splenectomy sample $(n=3)$ or $B M$ biopsy $(n=1)$. A cytology review of blood smears and/or BM aspirate smears was performed in 28 of the 47 cases. The cytological criteria described by Matutes et al. were used to identify a typical MZL aspect (Matutes, et al 2008). For comparative purposes, blood smears of 10 SMZL cases (with a confirmed diagnosis after the histological assessment of a splenectomy sample) known to lack $t(2 ; 7)(p 11 ; q 21)$ or a variant were reviewed at the same time. The cytology review was performed by three expert cytologists (KM, MP, and CLL). 
Molecular analyses were performed on DNA extracted from whole blood $(n=28)$ or from cytogenetic pellets ( $n=9$ ). IGH sequences were analyzed as described previously (Ghia, et al 2007). For cases of $\mathrm{CLL} / \mathrm{MBL} / \mathrm{SLL}$, the IGHV genes were considered to be unmutated if the percentage identity with the germline counterparts was $\geq 98 \%$ (Ghia, et al 2007). For the other cases, sequences were considered to be unmutated (100\% identity), minimally or borderline mutated $(99.9 \%-97 \%)$ or significantly mutated (<97\% identity), according to the criteria published by Bikos et al. (Bikos, et al 2012) for MZL.

Mutation hotspots in the TP53 gene (exons 4-9) and NOTCH2 gene (exon 34) were analyzed by Sanger sequencing, as described previously (Kiel, et al 2012, Pospisilova, et al 2012). The MYD88 L625P mutation was detected using real-time allele-specific PCR, as described previously (Xu, et al 2013).

\section{Statistical analysis}

Overall survival (OS) was defined as the time interval between diagnosis and death or last follow-up. Categorical variables were compared using a Fisher's exact test, whereas continuous variables were compared using the Mann-Whitney test. OS was estimated according to the Kaplan-Meier (KM) method. A log-rank test was used to compare the survival curves. A Cox proportional hazards model was used to determine hazard ratios and $95 \%$ confidence intervals. Median follow-up was calculated with the reverse KM method. All tests were two-sided, and the threshold for statistical significance was set to $p<0.05$. All statistical analyses were performed using IBM SPSS Statistics software for Windows (version 25.0, IBM, Armonk, NY).

\section{RESULTS}

Characteristics of the study population, and cytology reviews

Among 17752 patients with mature B-cell neoplasms, 57 (0.32\%) carried a $\mathrm{t}(C D K 6)$. The characteristics of the study population are summarized in Table I. There was a predominance of males ( $n=36,63 \%)$, and the median (range) age at diagnosis was 69 (35-90). Thirteen of the $48(27 \%)$ patients with data presented with splenomegaly, and 9 out of 49 (18\%) had lymphadenopathy. The median (range) lymphocyte count was 7.2 G/L (1-112.4). All 10 cases (100\%) of CLL/MBL/SLL and 26 of the 47 (55\%) cases of MZL/unclassified small B-cell lymphoma (SmBL) patients expressed CD5 (Supplemental Table S1). 
The initial diagnoses were CLL $(n=6)$, high-count CLL-like MBL $(n=2)$, small lymphocytic lymphoma (SLL, n=2), B-PLL ( $n=3)$, SMZL ( $n=25)$, nodular MZL (NMZL) ( $n=1$ ), bronchus-associated lymphoid tissue (BALT) lymphoma $(n=1)$, and unclassified SmBL $(n=17)$. Six out of $10 \mathrm{CLL} / \mathrm{MBL} / \mathrm{SLL}$ cases were reviewed, and were found to have a high proportion of mature lymphocytes and no prolymphocytic cells. The three cases diagnosed as B-PLL were reclassified as SMZL, since the proportion of prolymphocytic cells was in fact below $55 \%$ (ranging from $12 \%$ to $48 \%$ of the lymphoid blood cells), and the prolymphocytic cells were mixed with MZL cells (Supplementary Fig S1). Fifteen of the 25 SMZL were reviewed: they were found to have an SMZL aspect: six displayed a typical morphological aspect (according to Matutes' criteria) and 9 exhibited some atypical features consisting in the presence of prolymphocytic cells (median (range) proportion of lymphoid cells: 7\% [3-22]). Among the 17 unclassified cases of SmBL, 6 had a BM biopsy whose aspect did not enable us to classify the type of lymphoma more precisely. Six of the 17 cases of SmBL were cytologically reviewed: one had a typical SMZL aspect, and 5 had an aspect compatible with SMZL but with some atypia: prolymphocytic cells (median (range) proportion of lymphoid cells: 8\% [6-30]) were associated with classical marginal zone cells. In all, 47 cases were classified as SmBL, including 36 cases of MZL (34 SMZL, 1 NMZL and 1 BALT) and 10 cases of CLL/MBL/SLL (Table I and Supplementary Table S1).

In the 10 reviewed cases of SMZL lacking t $(2 ; 7)$ or a variant, the blood smears showed a typical SMZL aspect according to Matutes' criteria, with very few or no prolymphocytic cells (median (range): $1 \%$ [0-5]) (Supplemental Table S2).

\section{Cytogenetic analysis}

The karyotyping and FISH results are summarized in Supplemental Table S3. The FISH analysis confirmed the involvement of $C D K 6$ in all 57 cases. A t(2;7)(p11;q21) was found in 51 of the 57 (89\%) patients, with an additional derivative chromosome 7 from $t(2 ; 7)$ in 4 of the 51 . Forty-seven cases were analyzed with an IGK break-apart FISH probe. In the majority of the patients ( $n=33$ out of 47, 70\%), the breakpoint in IGK was located in the proximal region. In 14 patients (30\%), the breakpoint was more centromeric (in the IGKV distal region)(Supplemental Fig S2).

Two cases (one CLL and one SLL) had a t(7;14)(q21;q32) IGH/CDK6 and four (two SMZL and two CLL) had a $t(7 ; 14)(q 21 ; q 11)$ - a previously undescribed translocation involving the CDK6 and TRA/TRD loci (TRAD) (as proven by a FISH analysis; Fig S3).

The $\mathrm{t}(C D K 6)$ was the sole abnormality detected by karyotyping in 19 of the 57 (33\%) patients, including 3 of the $4 t(7 ; 14)$ TRAD/CDK6 cases and 1 of the $2 t(7 ; 14) I G H / C D K 6$ cases. When the 
translocation was not isolated, it was never a secondary event: it was present in the primary clone in 22 cases, found concomitantly with other chromosomal abnormalities in 12 cases, and found in an independent clone in 4 cases.

Twenty-eight (49\%) patients exhibited a CK, and 18 of these (32\%) exhibited a HCK. The median (range) number of chromosomal abnormalities was 2 (1-14). The most frequent chromosomal abnormality associated with $\mathrm{t}(C D K 6)$ was a $17 \mathrm{p}$ deletion involving the TP53 gene [del(17p)], which was detected in 23 of the 57 (40\%) patients. The other frequent aberrations were as follows: 13q14 deletion [del(13q)] in 22/54 (39\%), 8p deletion [del(8p)] in 14/57 (25\%), trisomy 3 in 10/57 (18\%), 8q gain in 7/57 (12\%), trisomy 12 in 6/57 (11\%), and trisomy 18 in 4/57 (7\%) (Table I and Fig 1). Deletion of 7q [del(7q)] was observed in only one patient (patient \#17 in Supplemental Table S3): a case of SMZL in which $\mathrm{t}(2 ; 7)$ and del(7q) were found in independent clones.

The $17 p$ deletion was significantly associated with the presence of prolymphocytic cells $(93 \%$ in the del(17p) subgroup vs. $24 \%$ in the subgroup lacking del(17p), p<0.001), TP53 mutation (60\% vs. 10.5\%; $p=0.002)$, CK (78\% vs. 29\%; $p<0.001)$, HCK (61\% vs. $12 \%$; $p<0.001)$, a higher number of chromosomal abnormalities (median(range) 5 (2-13) vs. 1 (1-6); $p<0.001)$, del(13q) (59\% vs. $28 \% ; p=0.028)$, del( $8 p$ ) ( $48 \%$ vs. $9 \% ; p=0.001)$, and $8 q$ gain ( $26 \%$ vs. $3 \% ; p=0.014)$. The correlations between del(17p) and these parameters were also statistically significant when considering only the 47 cases of MZL/SmBL, except for del(13q) (Supplemental Table S4).

\section{Molecular analysis}

TP53 gene sequencing revealed the presence of a mutation in 10 of the $36(27 \%)$ tested patients. All the mutations affected the DNA-binding domain (Supplemental Fig S4). The TP53 mutation was associated with a del(17) in 9 of the 10 patients. Overall, the TP53 gene was disrupted (i.e. mutated and/or deleted) in 24 of the 44 (55\%) tested patients.

A MYD88 L265P mutation was found in 5 of the 37 patients, all in the MZL/SmBL subgroup. Sequencing of exon 34 of the NOTCH2 gene did not reveal any mutations in the 27 tested patients.

IGHV genes were sequenced in 37 patients. The IGHV genes were mutated in 5 of 8 cases of CLL/MBL/SLL. The great majority of MZL/SmBL cases (25/29, 86\%) carried mutations and 20 of these were significantly mutated ( $<97 \%$ homology). Eighteen different IGHV genes were identified among the 29 cases; the most frequent were V3-23 (4/29, 14\%) and V4-59 (3/29, 10\%) (Fig 1). 


\section{Survival analysis}

The median follow-up time after diagnosis was 54 months. Twenty-eight of the 57 patients (49\%) had been treated. The characteristics of these treatments are summarized in Supplemental Table S5. We assessed survival in the cohort as a whole $(n=57)$ and in the MZL/SmBL subgroup $(n=47)$ but not (given the small sample size) in the CLL/SLL/MBL subgroup. The median OS time was not attained in the cohort as a whole or in the MZL/SmBL subgroup. The calculated OS was $81 \%$ at 5 years and $73 \%$ at 10 years for the entire cohort, and $82 \%$ at both 5 and 10 years for the 47 patients with MZL/SmBL (Table I). The presence of del(17p) or a TP53 mutation did not appear to influence survival in the cohort as a whole ( $p=0.197$ and $p=0.627$, respectively) (Table $\|$ and Fig 2 ) or in the MZL/SmBL subgroup ( $p=0.426$ and $p=0.333$, respectively) (Supplemental Table S6 and Fig S5).

\section{DISCUSSION}

Here, we report a large cohort of patients with mature B-cell neoplasm and a $t(2 ; 7)(p 11 ; q 21)$ translocation or variants involving CDK6.

The $\mathrm{t}(C D K 6)$ was the sole anomaly in $33 \%$ of the patients. When accompanied by other abnormalities, $\mathrm{t}(C D K 6)$ was never found in a subclone - suggesting that $\mathrm{t}(C D K 6)$ is possibly a primary pathogenic event. The majority of the patients $(89 \%)$ displayed a $t(2 ; 7)$ involving the IGK locus. Only two cases harbored a variant translocation with rearrangement of the IGH locus. In four cases, we identified the TRAD locus as a $\mathrm{t}(C D K 6)$ partner for the first time.

We found this translocation in two cases of CLL and two cases of SMZL. The fact that the translocation was isolated in three of the four cases suggests that it is a "driver" genetic event in pathogenesis. Moreover, given the involvement of the TRAD locus, the translocation might have occurred at an early step in lymphoid differentiation. In mature B-cell neoplasms, 14q11 translocations are very rare. Eighteen cases are listed in the Mitelman database (https://mitelmandatabase.isb-cgc.org), 13 of which are CLL. The involvement of the TRAD locus has been proven by FISH analysis in only a few cases with MYC or NKX2-5 locus rearrangement (Lau, et al 2008, Put, et al 2012, Su, et al 2008). Since the TCR enhancers are known to be lymphoid specific but not T-cell restricted, the functional consequence of these rearrangements is transcriptional activation of the partner genes. Hence, as seen for IGK/CDK6 (Brito-Babapulle, et al 2002, Corcoran, et al 1999), $\mathrm{t}(7 ; 14)$ TRAD/CDK6 results in overexpression of CDK6. However, a lack of material prevented us from evaluating CDK6 expression. Dual CDK4/6 inhibitors are currently under 
development, with promising preclinical and clinical results in mature B-cell malignancies (Martin, et al 2019, Tanaka, et al 2020). They may represent a therapeutic option in patients with $\mathrm{t}(C D K 6)$.

CLL/MBL/SLL cases. Of the 57 cases of $\mathrm{t}(C D K 6), 10$ had a diagnosis of CLL, CLL-like MBL or SLL (confirmed by clinical findings, cytology, and immunophenotyping, with a Matutes score of 4 or 5), including two cases with $t(7 ; 14)(q 21 ; q 32) C D K 6 / I G H$ and two cases with $t(7 ; 14)(q 21 ; q 11)$ CDK6/TRAD. Our results confirmed that (i) $\mathrm{t}(C D K 6)$ is very rare in $\mathrm{CLL}$ and related diseases, (ii) variant translocations are frequent in this subgroup (4/10 cases), and (iii) CDK6/IGH is restricted to this subgroup (Hayette, et al 2003).

MZL/SmBL. In the present study, $\mathrm{t}(C D K 6)$ was mostly associated with MZL (36/47, 76\%). SMZL is difficult to diagnose. According to Matutes et al., the minimum criteria are either spleen histology results and an immunophenotype or (if a histological assessment of the spleen is unavailable) typical blood and BM morphologies, an immunophenotype, and intrasinusoidal infiltration by CD20-positive cells (Matutes, et al 2008). About 20-25\% of cases of SMZL are CD5+ (Matutes, et al 2008, Salido, et al 2010). However, a histological analysis is not always performed when there is no indication for treatment, and SMZL is often only diagnosed after other types of low-grade B-cell lymphoma have been ruled out. In the present study, a histological analysis was not available for the majority of patients. The strong suspicion of SMZL was based on cytological and immunophenotyping data. In our series, the Matutes score was 3 or less for all 27 patients with available data, and more than a half of these were CD5+. In the absence of lymphoid cells with cleaved nuclei and a translocation involving BCL2, the diagnosis of follicular lymphoma was very unlikely. All CD5+ MZL/SmBL cases in our cohort $(n=26 / 47,55 \%)$ lacked $t(11 ; 14)(q 13 ; q 32)$, which rules out a diagnosis of leukemic nonnodal mantle cell lymphoma (MCL, in which this aberration is always present). We cannot formally rule out the possibility that CD5+ cases were $t(11 ; 14) / c y c l i n-D 1-n e g a t i v e ~ M C L s$. However, the absence of generalized lymphadenopathy at diagnosis and the indolent clinical course argued against a diagnosis of MCL (Swerdlow, et al 2017). A differential diagnosis of lymphoplasmacytic lymphoma could be considered in two patients exhibited a MYD88 L265P mutation and IgM monoclonal paraprotein (patients \#23 and \#20). Neither patient had plasma cells, and one presented with villous lymphocytes in the initial cytological assessment. In 11 patients, a cytology review could not be performed and so the initial diagnosis of SmBL could not be refined. However, by a process of elimination, we hypothesized that these 11 cases were also related to MZL, as $t(2 ; 7)(p 11 ; q 21)$ translocation is very strongly biased to B-cell lymphoproliferation of marginal-zone origin (Xochelli, et al 2014).

In our series, cases of MZL $\mathrm{t}(C D K 6)+$ frequently featured prolymphocytic cells in a cytological assessment $(18 / 26,69 \%)$. These prolymphocytes were mixed with a lymphoid population having the 
features of MZL cells, and so we considered these to be "atypical" cases of MZL. Prolymphocytic cells (defining B-PLL if they account for more than $55 \%$ of lymphoid cells in a de novo context (Swerdlow, et al 2017) can typically be observed as CLL progresses (Kjeldsberg and Marty 1981) and in a leukemic form of MCL (Ruchlemer, et al 2004). In contrast, the presence of prolymphocytic cells in MZL is unusual and has been reported in a few cases with transformed splenic B-cell lymphoma only (Algashaamy, et al 2018, Hoehn, et al 2012). The association between prolymphocytic cells and nontransformed $\mathrm{t}(C D K 6)+\mathrm{MZL}$ is intriguing and seems to be a particular feature of these cases of MZL, as few or no prolymphocytic cells were observed in cases of SMZL without $t(C D K 6)$. The presence of prolymphocytes was correlated with the presence of del(17p) but not with OS.

We found that del(17p) and the TP53 mutation were respectively present in $47 \%$ and $33 \%$ of cases of MZL/SmBL $t(C D K 6)+$. These frequencies are higher than those observed in classical SMZL, in which del(17p) is detected in $18-33 \%$ of patients and a TP53 mutation is detected in 15-16\% (Jaramillo Oquendo, et al 2019, Parry, et al 2015, Salido, et al 2010) (Supplemental Table S7). Interestingly, del(7q) is the most frequent abnormality in SMZL (19-39\% (Parry, et al 2015, Salido, et al 2010)) but we detected it only in one case. The deletion was present in a distinct clone that lacked $t(2 ; 7)-$, suggesting that these two aberrations are mutually exclusive.

We found IGHV gene mutations in $86 \%$ of the patients with MZL/SmBL $t(C D K 6)+$; this frequency is similar to that found in cases of SMZL (Bikos, et al 2012, Salido, et al 2010). However, the IGHV usage profile observed in our $\mathrm{t}(C D K 6)+$ patients differed: we did not find any cases harboring an IGHV1$02{ }^{*} 04$ gene, while the latter is the most frequent allele (25\%) in classical SMZL (Bikos, et al 2012).. Lastly, we did not find any patients with a mutation in the NOTCH2 gene - the most frequently mutated gene in SMZL, and which accounts for about 20\% of cases (Jaramillo Oquendo, et al 2019, Rossi, et al 2012).

Overall survival was good in our series of MZL/SmBL $\mathrm{t}(C D K 6)+$ cases: the 5-year OS rate was above $80 \%$. This was in line with the favorable prognosis usually observed in SMZL (Arcaini, et al 2016). In SMZL, the presence of a TP53 deletion or TP53 mutations is reportedly an independent marker of poor OS (Parry, et al 2015, Salido, et al 2010). In our series of $\mathrm{t}(C D K 6)+$ lymphomas, TP53 abnormalities were not significantly associated with poor OS. However, the median follow-up time was only 45 months, which prevents us from drawing definitive conclusions.

In summary, our present results demonstrated that CDK6 translocations mainly involved the IGK locus and very rarely the IGH or TRAD loci. The latter partner was reported for the first time in the present study. We confirmed that $\mathrm{t}(C D K 6)$ are rare events in $\mathrm{CLL} / \mathrm{MBL}$ and $\mathrm{SLL}$, and that they frequently involve alternative partners (IGH or TRAD). This large series extended our biological and molecular knowledge of a rare aberration in non-CLL B-cell lymphoproliferative disease. Our results 
suggest that most cases of $\mathrm{t}(\mathrm{CDK} 6+)$ constitute a particular subgroup of $\mathrm{B}$-cell marginal zone lymphomas with distinctive features: prolymphocytic cells, frequent CD5 expression, a high frequency of TP53 deletion and mutation, a low frequency of 7q deletion, and the absence of IGHV1$2 * 04$ and NOTCH2 mutation. The $\mathrm{t}(C D K 6)+$ lymphomas are indolent. Patients have a good OS, which is apparently not influenced by the presence of a TP53 aberration. In case of disease progression, CDK6 may represent a therapeutic target with new CDK4/6 inhibitors.

Acknowledgments: We thank Luce Smagghe, Clémentine Gabillaud, Laura Daussin, and Lucile Gilot for expert technical assistance, and Thierry Soussi for helpful discussion.

Authorship: $B G a, P C L, K M, M P, C L L, B G r, L J$ and $E C$ performed the research. $B G a, P C L, K M, M P, C L L$, QHL and EC analyzed data. $L M, N N, A I, S S, C L, J B G, M L P, E B, D P, C B, M A C R, M J P, S R, P L, S D, I R W, A B$ provided samples and clinical data. BGa, $\mathrm{PCL}, \mathrm{FNK}$ and $\mathrm{EC}$ designed the research study. $\mathrm{BGa}, \mathrm{PCL}, \mathrm{SAS}$, FNK and EC wrote the paper. 


\section{REFERENCES}

Algashaamy, K., Tan, Y., Mackrides, N., Alencar, A., Peng, J.H., Rosenblatt, J., Alderuccio, J.P., Lossos, I.S., Vega, F. \& Chapman, J. (2018) Splenic B-Cell Lymphomas with Diffuse Cyclin D1 Protein Expression and Increased Prolymphocytic Cells: A Previously Unrecognized Diagnostic Pitfall. Case Rep Hematol, 2018, 5761953.

Arcaini, L., Rossi, D. \& Paulli, M. (2016) Splenic marginal zone lymphoma: from genetics to management. Blood, 127, 2072-2081.

Baro, C., Salido, M., Espinet, B., Astier, L., Domingo, A., Granada, I., Milla, F., Carrio, A., Costa, D., Luno, E., Hernandez, J.M., Campo, E., Florensa, L., Ferrer, A., Salar, A., Bellosillo, B., Besses, C., Serrano, S. \& Sole, F. (2008) New chromosomal alterations in a series of 23 splenic marginal zone lymphoma patients revealed by Spectral Karyotyping (SKY). Leuk Res, 32, 727736.

Bikos, V., Darzentas, N., Hadzidimitriou, A., Davis, Z., Hockley, S., Traverse-Glehen, A., Algara, P., Santoro, A., Gonzalez, D., Mollejo, M., Dagklis, A., Gangemi, F., Bosler, D.S., Bourikas, G., Anagnostopoulos, A., Tsaftaris, A., lannitto, E., Ponzoni, M., Felman, P., Berger, F., Belessi, C., Ghia, P., Papadaki, T., Dogan, A., Degano, M., Matutes, E., Piris, M.A., Oscier, D. \& Stamatopoulos, K. (2012) Over $30 \%$ of patients with splenic marginal zone lymphoma express the same immunoglobulin heavy variable gene: ontogenetic implications. Leukemia, 26, 1638-1646.

Brito-Babapulle, V., Gruszka-Westwood, A.M., Platt, G., Andersen, C.L., Elnenaei, M.O., Matutes, E., Wotherspoon, A.C., Weston-Smith, S.G. \& Catovsky, D. (2002) Translocation t(2;7)(p12;q2122) with dysregulation of the CDK6 gene mapping to 7q21-22 in a non-Hodgkin's lymphoma with leukemia. Haematologica, 87, 357-362.

Cavazzini, F., Hernandez, J.A., Gozzetti, A., Russo Rossi, A., De Angeli, C., Tiseo, R., Bardi, A., Tammiso, E., Crupi, R., Lenoci, M.P., Forconi, F., Lauria, F., Marasca, R., Maffei, R., Torelli, G., Gonzalez, M., Martin-Jimenez, P., Maria Hernandez, J., Rigolin, G.M. \& Cuneo, A. (2008) Chromosome $14 q 32$ translocations involving the immunoglobulin heavy chain locus in chronic lymphocytic leukaemia identify a disease subset with poor prognosis. Br J Haematol, 142, 529-537.

Chen, D., Law, M.E., Theis, J.D., Gamez, J.D., Caron, L.B., Vrana, J.A. \& Dogan, A. (2009) Clinicopathologic features of CDK6 translocation-associated B-cell lymphoproliferative disorders. Am J Surg Pathol, 33, 720-729.

Corcoran, M.M., Mould, S.J., Orchard, J.A., Ibbotson, R.E., Chapman, R.M., Boright, A.P., Platt, C., Tsui, L.C., Scherer, S.W. \& Oscier, D.G. (1999) Dysregulation of cyclin dependent kinase 6 expression in splenic marginal zone lymphoma through chromosome $7 \mathrm{q}$ translocations. Oncogene, 18, 6271-6277.

Cosson, A., Chapiro, E., Belhouachi, N., Cung, H.A., Keren, B., Damm, F., Algrin, C., Lefebvre, C., FertFerrer, S., Luquet, I., Gachard, N., Mugneret, F., Terre, C., Collonge-Rame, M.A., Michaux, L., Rafdord-Weiss, I., Talmant, P., Veronese, L., Nadal, N., Struski, S., Barin, C., Helias, C., Lafage, M., Lippert, E., Auger, N., Eclache, V., Roos-Weil, D., Leblond, V., Settegrana, C., Maloum, K., Davi, F., Merle-Beral, H., Lesty, C. \& Nguyen-Khac, F. (2014) 14q deletions are associated with trisomy 12, NOTCH1 mutations and unmutated IGHV genes in chronic lymphocytic leukemia and small lymphocytic lymphoma. Genes Chromosomes Cancer, 53, 657-666.

Douet-Guilbert, N., Tous, C., Le Flahec, G., Bovo, C., Le Bris, M.J., Basinko, A., Morel, F. \& De Braekeleer, M. (2014) Translocation $t(2 ; 7)(p 11 ; q 21)$ associated with the CDK6/IGK rearrangement is a rare but recurrent abnormality in B-cell lymphoproliferative malignancies. Cancer Genet, 207, 83-86. 
Fink, S.R., Smoley, S.A., Stockero, K.J., Paternoster, S.F., Thorland, E.C., Van Dyke, D.L., Shanafelt, T.D., Zent, C.S., Call, T.G., Kay, N.E. \& Dewald, G.W. (2006) Loss of TP53 is due to rearrangements involving chromosome region 17 p10 approximately p12 in chronic lymphocytic leukemia. Cancer Genet Cytogenet, 167, 177-181.

Ghia, P., Stamatopoulos, K., Belessi, C., Moreno, C., Stilgenbauer, S., Stevenson, F., Davi, F. \& Rosenquist, R. (2007) ERIC recommendations on IGHV gene mutational status analysis in chronic lymphocytic leukemia. Leukemia, 21, 1-3.

Hayette, S., Tigaud, I., Callet-Bauchu, E., Ffrench, M., Gazzo, S., Wahbi, K., Callanan, M., Felman, P., Dumontet, C., Magaud, J.P. \& Rimokh, R. (2003) In B-cell chronic lymphocytic leukemias, 7q21 translocations lead to overexpression of the CDK6 gene. Blood, 102, 1549-1550.

Hoehn, D., Miranda, R.N., Kanagal-Shamanna, R., Lin, P. \& Medeiros, L.J. (2012) Splenic B-cell lymphomas with more than $55 \%$ prolymphocytes in blood: evidence for prolymphocytoid transformation. Hum Pathol, 43, 1828-1838.

Jaramillo Oquendo, C., Parker, H., Oscier, D., Ennis, S., Gibson, J. \& Strefford, J.C. (2019) Systematic Review of Somatic Mutations in Splenic Marginal Zone Lymphoma. Sci Rep, 9, 10444.

Kiel, M.J., Velusamy, T., Betz, B.L., Zhao, L., Weigelin, H.G., Chiang, M.Y., Huebner-Chan, D.R., Bailey, N.G., Yang, D.T., Bhagat, G., Miranda, R.N., Bahler, D.W., Medeiros, L.J., Lim, M.S. \& Elenitoba-Johnson, K.S. (2012) Whole-genome sequencing identifies recurrent somatic NOTCH2 mutations in splenic marginal zone lymphoma. J Exp Med, 209, 1553-1565.

Kjeldsberg, C.R. \& Marty, J. (1981) Prolymphocytic transformation of chronic lymphocytic leukemia. Cancer, 48, 2447-2457.

Lau, L.C., Lim, P., Lim, Y.C., Teng, L.M., Lim, T.H., Lim, L.C., Tan, S.Y., Lim, S.T., Sanger, W.G. \& Tien, S.L. (2008) Occurrence of trisomy 12 , $t(14 ; 18)(q 32 ; q 21)$, and $t(8 ; 14)(q 24.1 ; q 11.2)$ in a patient with B-cell chronic lymphocytic leukemia. Cancer Genet Cytogenet, 185, 95-101.

Martin-Subero, J.I., Harder, L., Gesk, S., Schlegelberger, B., Grote, W., Martinez-Climent, J.A., Dyer, M.J., Novo, F.J., Calasanz, M.J. \& Siebert, R. (2002) Interphase FISH assays for the detection of translocations with breakpoints in immunoglobulin light chain loci. Int J Cancer, 98, 470474.

Martin, P., Bartlett, N.L., Blum, K.A., Park, S., Maddocks, K., Ruan, J., Ridling, L., Dittus, C., Chen, Z., Huang, X., Inghirami, G., DiLiberto, M., Chen-Kiang, S. \& Leonard, J.P. (2019) A phase 1 trial of ibrutinib plus palbociclib in previously treated mantle cell lymphoma. Blood, 133, 1201-1204.

Matutes, E. \& Catovsky, D. (1994) The value of scoring systems for the diagnosis of biphenotypic leukemia and mature B-cell disorders. Leuk Lymphoma, 13 Suppl 1, 11-14.

Matutes, E., Oscier, D., Montalban, C., Berger, F., Callet-Bauchu, E., Dogan, A., Felman, P., Franco, V., Iannitto, E., Mollejo, M., Papadaki, T., Remstein, E.D., Salar, A., Sole, F., Stamatopoulos, K., Thieblemont, C., Traverse-Glehen, A., Wotherspoon, A., Coiffier, B. \& Piris, M.A. (2008) Splenic marginal zone lymphoma proposals for a revision of diagnostic, staging and therapeutic criteria. Leukemia, 22, 487-495.

Moreau, E.J., Matutes, E., A'Hern, R.P., Morilla, A.M., Morilla, R.M., Owusu-Ankomah, K.A., Seon, B.K. \& Catovsky, D. (1997) Improvement of the chronic lymphocytic leukemia scoring system with the monoclonal antibody SN8 (CD79b). Am J Clin Pathol, 108, 378-382.

Oscier, D.G., Matutes, E., Gardiner, A., Glide, S., Mould, S., Brito-Babapulle, V., Ellis, J. \& Catovsky, D. (1993) Cytogenetic studies in splenic lymphoma with villous lymphocytes. Br J Haematol, 85, 487-491.

Parker, E., Macdonald, J.R. \& Wang, C. (2011) Molecular characterization of a t(2;7) translocation linking CDK6 to the IGK locus in CD5(-) monoclonal B-cell lymphocytosis. Cancer Genet, 204, 260-264.

Parry, M., Rose-Zerilli, M.J., Ljungstrom, V., Gibson, J., Wang, J., Walewska, R., Parker, H., Parker, A., Davis, Z., Gardiner, A., Mclver-Brown, N., Kalpadakis, C., Xochelli, A., Anagnostopoulos, A., Fazi, C., de Castro, D.G., Dearden, C., Pratt, G., Rosenquist, R., Ashton-Key, M., Forconi, F., Collins, A., Ghia, P., Matutes, E., Pangalis, G., Stamatopoulos, K., Oscier, D. \& Strefford, J.C. 
(2015) Genetics and Prognostication in Splenic Marginal Zone Lymphoma: Revelations from Deep Sequencing. Clin Cancer Res, 21, 4174-4183.

Pospisilova, S., Gonzalez, D., Malcikova, J., Trbusek, M., Rossi, D., Kater, A.P., Cymbalista, F., Eichhorst, B., Hallek, M., Dohner, H., Hillmen, P., van Oers, M., Gribben, J., Ghia, P., Montserrat, E., Stilgenbauer, S. \& Zenz, T. (2012) ERIC recommendations on TP53 mutation analysis in chronic lymphocytic leukemia. Leukemia, 26, 1458-1461.

Put, N., Van Roosbroeck, K., Konings, P., Meeus, P., Brusselmans, C., Rack, K., Gervais, C., NguyenKhac, F., Chapiro, E., Radford-Weiss, I., Struski, S., Dastugue, N., Gachard, N., Lefebvre, C., Barin, C., Eclache, V., Fert-Ferrer, S., Laibe, S., Mozziconacci, M.J., Quilichini, B., Poirel, H.A., Wlodarska, I., Hagemeijer, A., Moreau, Y., Vandenberghe, P. \& Michaux, L. (2012) Chronic lymphocytic leukemia and prolymphocytic leukemia with MYC translocations: a subgroup with an aggressive disease course. Ann Hematol, 91, 863-873.

Remstein, E.D., Law, M., Mollejo, M., Piris, M.A., Kurtin, P.J. \& Dogan, A. (2008) The prevalence of IG translocations and 7q32 deletions in splenic marginal zone lymphoma. Leukemia, 22, 12681272.

Rossi, D., Trifonov, V., Fangazio, M., Bruscaggin, A., Rasi, S., Spina, V., Monti, S., Vaisitti, T., Arruga, F., Fama, R., Ciardullo, C., Greco, M., Cresta, S., Piranda, D., Holmes, A., Fabbri, G., Messina, M., Rinaldi, A., Wang, J., Agostinelli, C., Piccaluga, P.P., Lucioni, M., Tabbo, F., Serra, R., Franceschetti, S., Deambrogi, C., Daniele, G., Gattei, V., Marasca, R., Facchetti, F., Arcaini, L., Inghirami, G., Bertoni, F., Pileri, S.A., Deaglio, S., Foa, R., Dalla-Favera, R., Pasqualucci, L., Rabadan, R. \& Gaidano, G. (2012) The coding genome of splenic marginal zone lymphoma: activation of NOTCH2 and other pathways regulating marginal zone development. J Exp Med, 209, 1537-1551.

Ruchlemer, R., Parry-Jones, N., Brito-Babapulle, V., Attolico, I., Wotherspoon, A.C., Matutes, E. \& Catovsky, D. (2004) B-prolymphocytic leukaemia with $t(11 ; 14)$ revisited: a splenomegalic form of mantle cell lymphoma evolving with leukaemia. Br J Haematol, 125, 330-336.

Salido, M., Baro, C., Oscier, D., Stamatopoulos, K., Dierlamm, J., Matutes, E., Traverse-Glehen, A., Berger, F., Felman, P., Thieblemont, C., Gesk, S., Athanasiadou, A., Davis, Z., Gardiner, A., Milla, F., Ferrer, A., Mollejo, M., Calasanz, M.J., Florensa, L., Espinet, B., Luno, E., Wlodarska, I., Verhoef, G., Garcia-Granero, M., Salar, A., Papadaki, T., Serrano, S., Piris, M.A. \& Sole, F. (2010) Cytogenetic aberrations and their prognostic value in a series of 330 splenic marginal zone B-cell lymphomas: a multicenter study of the Splenic B-Cell Lymphoma Group. Blood, $116,1479-1488$.

Su, X., Della-Valle, V., Delabesse, E., Azgui, Z., Berger, R., Merle-Beral, H., Bernard, O.A. \& NguyenKhac, F. (2008) Transcriptional activation of the cardiac homeobox gene CSX1/NKX2-5 in a Bcell chronic lymphoproliferative disorder. Haematologica, 93, 1081-1085.

Swerdlow, S.H., Campo, E., Harris, N.L., Jaffe, E.S., Pileri, S.A., Stein, H. \& Thiele, J. (2017) WHO Classification of Tumours of Haematopoietic and Lymphoid Tissues, Revised 4th Edition, Volume 2. International Agency for Research on Cancer (IARC).

Tanaka, Y., Momose, S., Tabayashi, T., Sawada, K., Yamashita, T., Higashi, M., Sagawa, M., Tokuhira, M., Rosenwald, A., Kizaki, M. \& Tamaru, J.I. (2020) Abemaciclib, a CDK4/6 inhibitor, exerts preclinical activity against aggressive germinal center-derived B-cell lymphomas. Cancer Sci, 111, 749-759.

Vahdati, M., Graafland, H. \& Emberger, J.M. (1983) Karyotype analysis of B-lymphocytes transformed by Epstein-Barr virus in 21 patients with B cell chronic lymphocytic leukemia. Hum Genet, 63, 327-331.

Xochelli, A., Baliakas, P., Moore, S., Sole, F., Wickham, N., Salido, M., Athanasiadou, A., Oscier, D. \& Stamatopoulos, K. (2014) Translocation $\mathrm{t}(2 ; 7)(\mathrm{p} 11.2 ; \mathrm{q} 21.2)$ : a rare genetic aberration associated with B-cell lymphoproliferative disorders of marginal-zone origin. Cancer Genet, 207, 281-283.

Xu, L., Hunter, Z.R., Yang, G., Zhou, Y., Cao, Y., Liu, X., Morra, E., Trojani, A., Greco, A., Arcaini, L., Varettoni, M., Brown, J.R., Tai, Y.T., Anderson, K.C., Munshi, N.C., Patterson, C.J., Manning, 
R.J., Tripsas, C.K., Lindeman, N.I. \& Treon, S.P. (2013) MYD88 L265P in Waldenstrom macroglobulinemia, immunoglobulin $\mathrm{M}$ monoclonal gammopathy, and other B-cell lymphoproliferative disorders using conventional and quantitative allele-specific polymerase chain reaction. Blood, 121, 2051-2058. 
Table 1. Characteristics of the study population.

\begin{tabular}{|c|c|c|c|c|c|c|c|}
\hline \multicolumn{2}{|c|}{ Parameter } & \multicolumn{2}{|c|}{ Whole cohort $(n=57)$} & \multicolumn{2}{|c|}{ MZL/SmBL cases $(n=47)$} & \multicolumn{2}{|c|}{$\begin{array}{c}\text { CLL/MBL/SLL cases } \\
(n=10)\end{array}$} \\
\hline \multirow{2}{*}{$\operatorname{Sex}(n, \%)$} & M & 36 & 63 & 28 & 60 & 8 & 80 \\
\hline & $\mathrm{F}$ & 21 & 47 & 19 & 40 & 2 & 20 \\
\hline Age at diagnosis & median (range) & $69(3$ & & 691 & & 681 & \\
\hline \multirow{2}{*}{$\begin{array}{c}\text { Lymphadenopathy (n, } \\
\%)\end{array}$} & no & 40 & 82 & 37 & 88 & 3 & 43 \\
\hline & yes & 9 & 18 & 5 & 12 & 4 & 57 \\
\hline \multirow{2}{*}{ Splenomegaly (n, \%) } & no & 35 & 73 & 32 & 78 & 3 & 43 \\
\hline & yes & 13 & 27 & 9 & 22 & 4 & 57 \\
\hline \multirow{2}{*}{ Treated (n, \%) } & no & 29 & 51 & 27 & 57 & 2 & 20 \\
\hline & yes & 28 & 49 & 20 & 43 & 8 & 80 \\
\hline $\begin{array}{l}\text { Time to first } \\
\text { treatment (months) }\end{array}$ & median (range) & $27(c$ & & 27 & & $7(1$ & \\
\hline \multirow{6}{*}{$\begin{array}{l}\text { Number of lines of } \\
\text { treatment }(n, \%)\end{array}$} & 0 & 29 & 51 & 27 & 55 & 2 & 20 \\
\hline & 1 & 17 & 30 & 14 & 36 & 3 & 30 \\
\hline & 2 & 4 & 7 & 3 & 3 & 1 & 10 \\
\hline & 3 & 3 & 5 & 1 & 3 & 2 & 20 \\
\hline & 4 & 3 & 5 & 1 & 0 & 2 & 20 \\
\hline & 5 & 1 & 2 & 1 & 3 & 0 & 0 \\
\hline Follow-up (months) & median $(95 \% \mathrm{Cl})$ & $54(33$ & & $45(23$ & & 7510 & \\
\hline \multirow{3}{*}{$\begin{array}{l}\text { Overall survival } \\
\qquad[95 \% \mathrm{CI}])\end{array}$} & at 1 year & \multicolumn{2}{|c|}{90.1 [82.1-98.8] } & \multicolumn{2}{|c|}{90.3 [81.6-99.9] } & \multirow{2}{*}{\multicolumn{2}{|c|}{ Not calculated* }} \\
\hline & at 5 years & $81.2[6$ & & $82.3[6$ & & & \\
\hline & at 10 years & $73.1[5$ & & $82.3[6$ & & & \\
\hline \multirow{2}{*}{ Paraprotein (n, \%) } & no & 26 & 63 & 24 & 63 & 2 & 67 \\
\hline & yes & 15 & 37 & 14 & 37 & 1 & 33 \\
\hline $\begin{array}{l}\text { Lymphocytosis at } \\
\text { diagnosis (G/L) }\end{array}$ & median (range) & \multicolumn{2}{|c|}{$7.2(1-112.4)$} & \multicolumn{2}{|c|}{$7.3(1-55.5)$} & \multicolumn{2}{|c|}{$5.4(1.96-112.4)$} \\
\hline $\begin{array}{l}\text { Hemoglobin level at } \\
\text { diagnosis (g/dL) }\end{array}$ & median (range) & \multicolumn{2}{|c|}{$13.3(5.6-16.9)$} & \multicolumn{2}{|c|}{$13.6(5.6-16.9)$} & \multicolumn{2}{|c|}{$13(8.1-14.3)$} \\
\hline $\begin{array}{l}\text { Platelet count at } \\
\text { diagnosis (G/L) }\end{array}$ & median (range) & \multicolumn{2}{|c|}{$205(27-363)$} & \multicolumn{2}{|c|}{$208(27-363)$} & \multicolumn{2}{|c|}{$183(86-344)$} \\
\hline \multirow{2}{*}{$\begin{array}{l}\text { Prolymphocytic cells } \\
\qquad(\mathrm{n}, \%)\end{array}$} & no & 14 & 44 & 8 & 31 & 6 & 100 \\
\hline & yes & 18 & 56 & 18 & 69 & 0 & 0 \\
\hline \multirow{2}{*}{ CD5 expression ( $n, \%)$} & no & 21 & 37 & 21 & 45 & 0 & 0 \\
\hline & yes & 36 & 63 & 26 & 55 & 10 & 100 \\
\hline \multirow{2}{*}{$\begin{array}{l}\text { Light chain expression } \\
\qquad(\mathrm{n}, \%)\end{array}$} & Kappa & 33 & 59 & 29 & 63 & 4 & 40 \\
\hline & Lambda & 23 & 41 & 17 & 37 & 6 & 60 \\
\hline \multirow{2}{*}{ Matutes score (n, \%) } & 0 & 8 & 16 & 8 & 20 & 0 & 0 \\
\hline & 1 & 19 & 38 & 19 & 47.5 & 0 & 0 \\
\hline
\end{tabular}




\begin{tabular}{|c|c|c|c|c|c|c|c|}
\hline & 2 & 10 & 25 & 10 & 25 & 0 & 0 \\
\hline & 3 & 3 & 6 & 3 & 7.5 & 0 & 0 \\
\hline & 4 or 5 & 10 & 25 & 0 & 0 & 10 & 100 \\
\hline $\begin{array}{l}\text { Number of } \\
\text { chromosomal } \\
\text { abnormalities } \\
\text { (karyotype) }\end{array}$ & median (range) & $2(1-14)$ & & $2(1-14)$ & & $2.5(1-5)$ & \\
\hline \multirow{2}{*}{$\begin{array}{l}\text { Isolated } t(C D K 6) \text { (by } \\
\text { karyotype) (n, \%) }\end{array}$} & no & 38 & 67 & 31 & 66 & 7 & 70 \\
\hline & yes & 19 & 33 & 16 & 33 & 3 & 30 \\
\hline \multirow{2}{*}{$\begin{array}{c}\text { Complex karyotype (n, } \\
\%)\end{array}$} & no & 29 & 51 & 24 & 51 & 5 & 50 \\
\hline & yes & 28 & 49 & 23 & 49 & 5 & 50 \\
\hline \multirow{2}{*}{$\begin{array}{l}\text { Highly complex } \\
\text { karyotype }(n, \%)\end{array}$} & no & 39 & 68 & 32 & 68 & 7 & 70 \\
\hline & yes & 18 & 32 & 15 & 32 & 3 & 30 \\
\hline \multirow{3}{*}{$\begin{array}{c}\text { Partners of CDK6 (n, } \\
\%)\end{array}$} & $\mathrm{t}(2 ; 7) / G K$ & 51 & 89 & 45 & 96 & 6 & 60 \\
\hline & $\mathrm{t}(7 ; 14) / G H$ & 2 & 4 & 0 & 0 & 2 & 20 \\
\hline & $\mathrm{t}(7 ; 14) T R A D$ & 4 & 7 & 2 & 4 & 2 & 20 \\
\hline \multirow{2}{*}{$\begin{array}{c}\text { Trisomy } 12(\mathrm{~K}+\mathrm{FISH}) \\
(\mathrm{n}, \%)\end{array}$} & no & 51 & 89 & 42 & 89 & 9 & 90 \\
\hline & yes & 6 & 11 & 5 & 11 & 1 & 10 \\
\hline \multirow{2}{*}{$\begin{array}{l}\text { 13q14 deletion (FISH) } \\
\text { (n, \%) }\end{array}$} & no & 32 & 61 & 26 & 59 & 6 & 60 \\
\hline & yes & 22 & 39 & 18 & 41 & 4 & 40 \\
\hline \multirow{2}{*}{$\begin{array}{l}\text { 11q/ATM deletion (K + } \\
\text { FISH) (n, \%) }\end{array}$} & no & 55 & 96 & 46 & 98 & 9 & 90 \\
\hline & yes & 2 & 3,5 & 1 & 2 & 1 & 10 \\
\hline \multirow{2}{*}{$\begin{array}{l}\text { 17p/TP53 deletion (K } \\
+ \text { FISH) }(n, \%)\end{array}$} & no & 34 & 60 & 25 & 53 & 9 & 90 \\
\hline & yes & 23 & 40 & 22 & 47 & 1 & 10 \\
\hline \multirow{2}{*}{$\begin{array}{l}\text { Trisomy 18/18q (K + } \\
\text { FISH) (n, \%) }\end{array}$} & no & 53 & 93 & 44 & 94 & 9 & 90 \\
\hline & yes & 4 & 7 & 3 & 6 & 1 & 10 \\
\hline \multirow{2}{*}{$\begin{array}{l}\text { Trisomy } 3 / 3 q(K+ \\
\text { FISH) }(n, \%)\end{array}$} & no & 47 & 82 & 38 & 81 & 9 & 90 \\
\hline & yes & 10 & 18 & 9 & 19 & 1 & 10 \\
\hline \multirow{2}{*}{$\begin{array}{c}8 q \text { gain }(K+F I S H)(n, \\
\%)\end{array}$} & no & 50 & 88 & 41 & 87 & 9 & 90 \\
\hline & yes & 7 & 12 & 6 & 13 & 1 & 10 \\
\hline \multirow{2}{*}{$\begin{array}{c}\text { 8p deletion (K) } \\
\%)\end{array}$} & no & 43 & 75 & 34 & 72 & 9 & 90 \\
\hline & yes & 14 & 25 & 13 & 28 & 1 & 10 \\
\hline \multirow{2}{*}{ IGHV genes $(\mathrm{n}, \%)$} & unmutated & 7 & 19 & 4 & 14 & 3 & 38 \\
\hline & mutated & 30 & 81 & 25 & 86 & 5 & 62 \\
\hline \multirow{2}{*}{ MYD88 L265P (n, \%) } & absence & 32 & 86 & 26 & 84 & 6 & 100 \\
\hline & presence & 5 & 14 & 5 & 16 & 0 & 0 \\
\hline \multirow{2}{*}{$\begin{array}{l}\text { TP53 mutation (n, } \\
\%)\end{array}$} & absence & 26 & 72 & 20 & 67 & 6 & 100 \\
\hline & presence & 10 & 28 & 10 & 33 & 0 & 0 \\
\hline \multirow{2}{*}{$\begin{array}{l}\text { TP53 disruption } \\
\text { (mutated and/or } \\
\text { deleted) (n, \%) }\end{array}$} & no & 20 & 45 & 14 & 38 & 6 & 86 \\
\hline & yes & 24 & 55 & 23 & 62 & 1 & 14 \\
\hline $\begin{array}{c}\text { NOTCH2 mutation ( } \mathrm{n} \text {, } \\
\% \text { ) }\end{array}$ & absence & 27 & 100 & 23 & 100 & 4 & 100 \\
\hline
\end{tabular}

MZL: marginal zone lymphoma; SmBL: small B-cell lymphoma; SLL: small lymphocytic lymphoma; CLL: chronic lymphocytic leukemia; MBL: monoclonal B-cell lymphocytosis; K: karyotyping; $\mathrm{Cl}$ : confidence interval; *: the sample was too small. 
Table II. Univariate analysis of overall survival, using the Kaplan Meier method.

\begin{tabular}{|c|c|c|c|c|c|c|c|c|c|}
\hline & & & ole c & $t(n=57)$ & & & MZL & $\mathrm{nBL}(\mathrm{n}=47)$ & \\
\hline Parameter & & $\begin{array}{c}\text { OS at } 5 \\
\text { years (\%) }\end{array}$ & HR & $95 \% \mathrm{Cl}$ & $P$-value & $\begin{array}{c}\text { OS at } 5 \\
\text { years (\%) }\end{array}$ & HR & $95 \% \mathrm{Cl}$ & P-value \\
\hline CD5 expression & negative & 90.5 & 151 & $037-612$ & 0566 & 90.5 & 151 & $028-825$ & 0633 \\
\hline & positive & 76.9 & $1 . J 1$ & & 0.500 & 78.4 & $1 . J 1$ & $0.20^{-0} 0.2 J$ & - \\
\hline Prolymphocytic cells & no & 81.3 & 123 & 02172 & 717 & 88.9 & 10 & 111050 & \\
\hline & yes & 78.0 & 1.35 & $24-7.37$ & 0.143 & 75.7 & 1.08 & $.11-10.52$ & 0.829 \\
\hline $\operatorname{Del}(17 p)$ & no & 86.6 & 226 & 062805 & 107 & 87.7 & 250 & 0501251 & م 212 \\
\hline & yes & 75.2 & 2.20 & נ & ועבוע & 79.3 & כ2.2 & 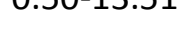 & $0.24 J$ \\
\hline TP53 mutated & no & 86.7 & 107 & 16 16 14 & 0627 & 92.3 & 232 & (26-41 07 & 0323 \\
\hline & yes & 90.9 & & & & 90.0 & כנ. & & תבנ.ט \\
\hline TP53 disrupted & no & 83.3 & 270 & $054-1353$ & 0465 & 90.0 & 343 & $040-2970$ & 0426 \\
\hline (mut and/or del) & yes & 78.2 & 2.10 & כ. $0.34-13$. & 0.400 & 80.9 & 0.45 & & $0.4 \angle 0$ \\
\hline
\end{tabular}

HR: Hazard ratio; $\mathrm{Cl}$ : confidence interval 
Figure 1. Distribution of recurrent cytogenetic and molecular abnormalities among the $\mathbf{5 7}$ patients. In the heat map, rows represent individual patients and columns correspond to aberrations. SLL: small lymphocytic lymphoma; CLL: chronic lymphocytic leukemia; MBL: monoclonal B-cell lymphocytosis; SMZL: splenic marginal zone lymphoma; USmBL: unclassified small B-cell lymphoma; NMZL: nodular marginal zone lymphoma; BALT: bronchus-associated lymphoid tissue lymphoma; PL cells: prolymphocytic cells; CK: complex karyotype; HCK: highly complex karyotype.

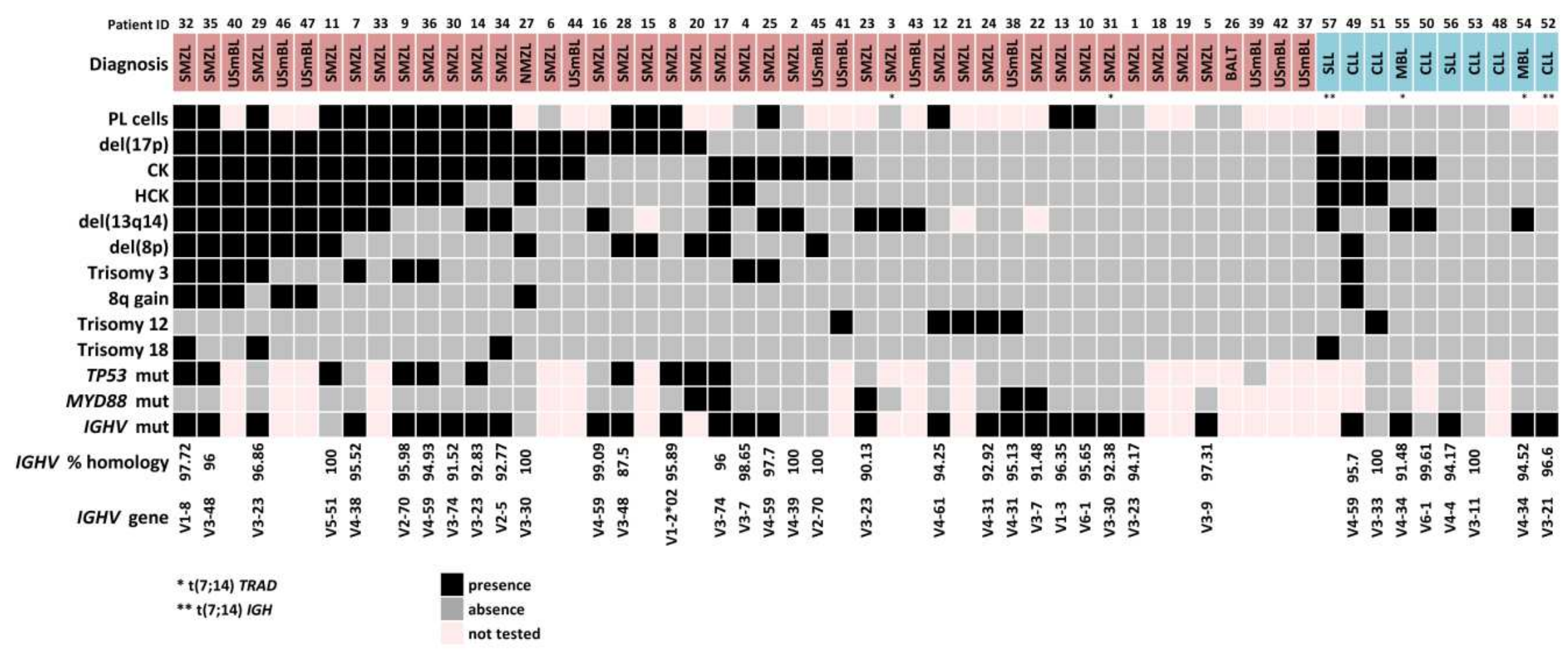


Figure 2. Kaplan-Meier estimates of OS, as a function of the $17 p$ deletion. A. For the cohort as a whole $(n=57)$. B. For cases of SMZL/SmBL ( $n=47)$.

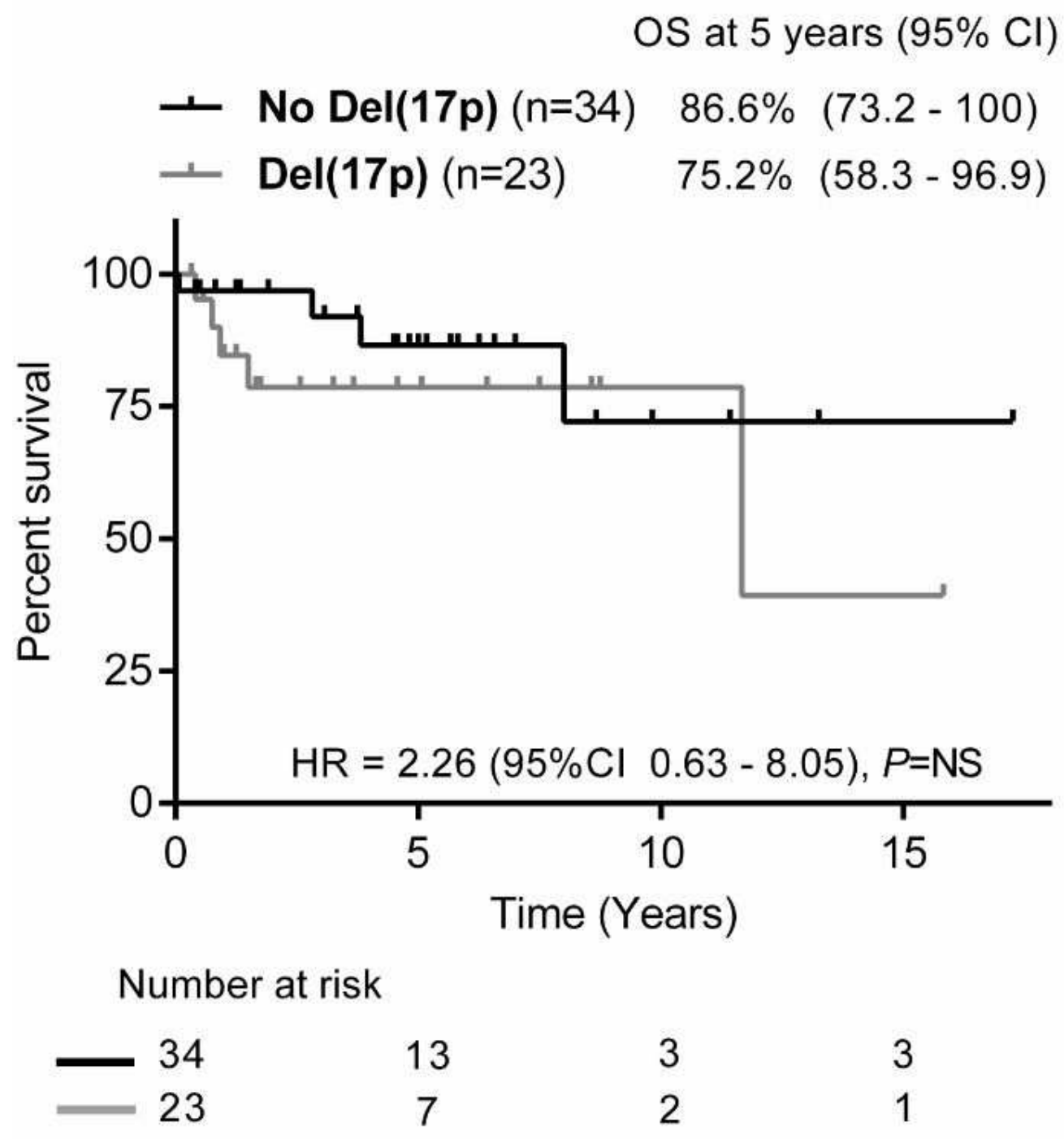



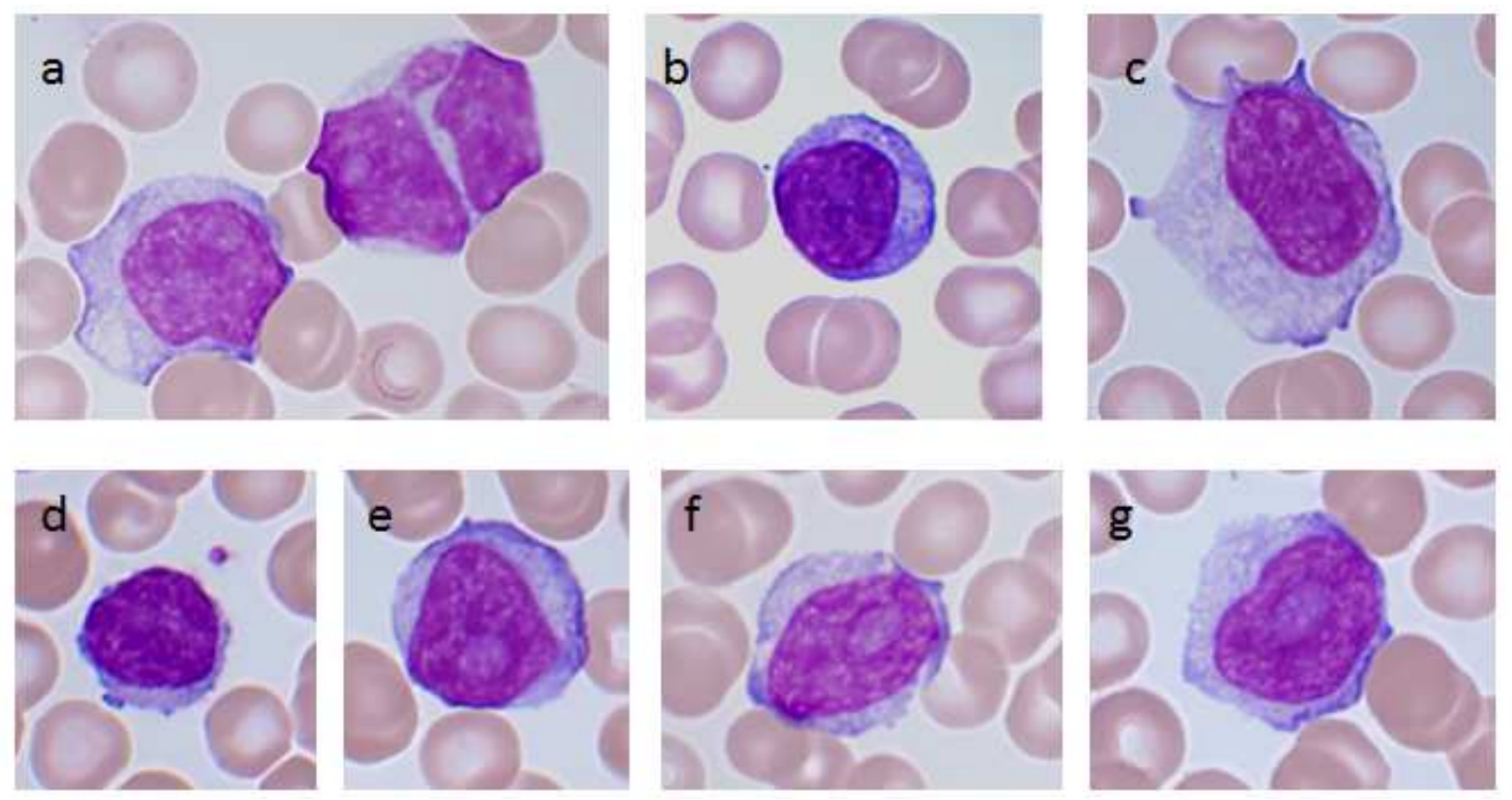

Supplemental Figure S1. Cytological aspect of an SMZL sample with prolymphocytic cells (case \#14). The sample features a pleomorphic lymphocytic population with MZL cells ( $a, b$ and $c)$, small lymphoid cells without specific features (d), and prolymphocytic cells (e, $f$ and $g$ ). 
A

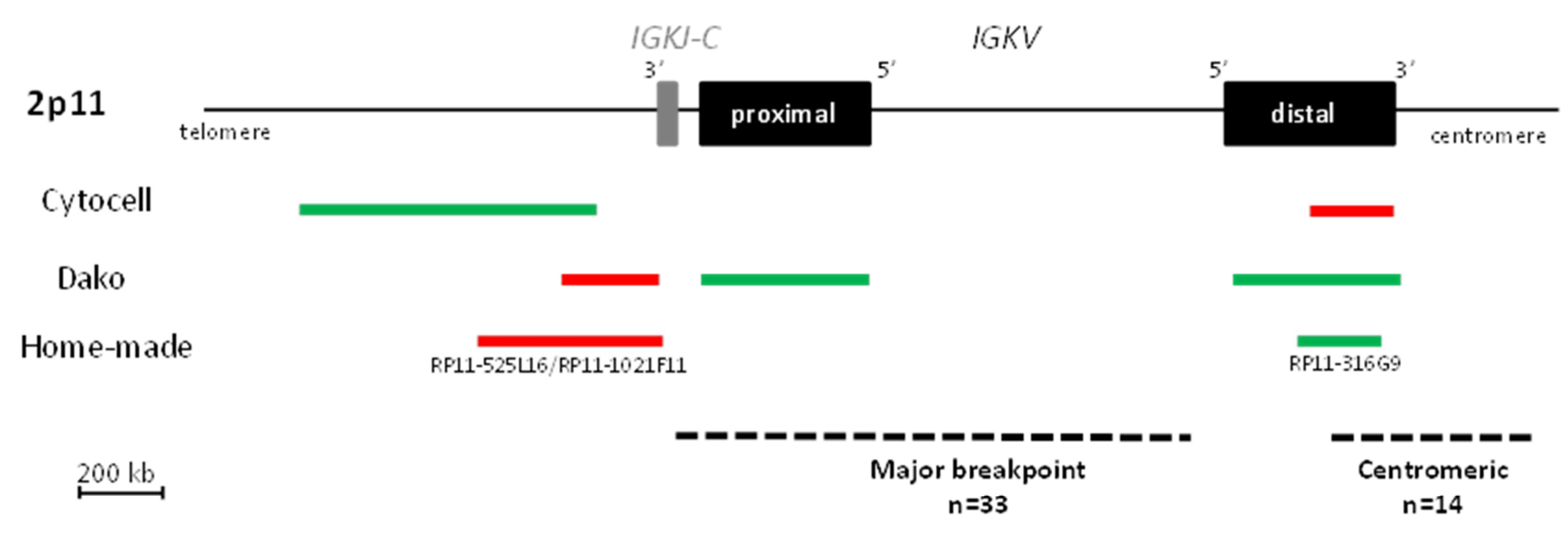

B

IGK Cytocell

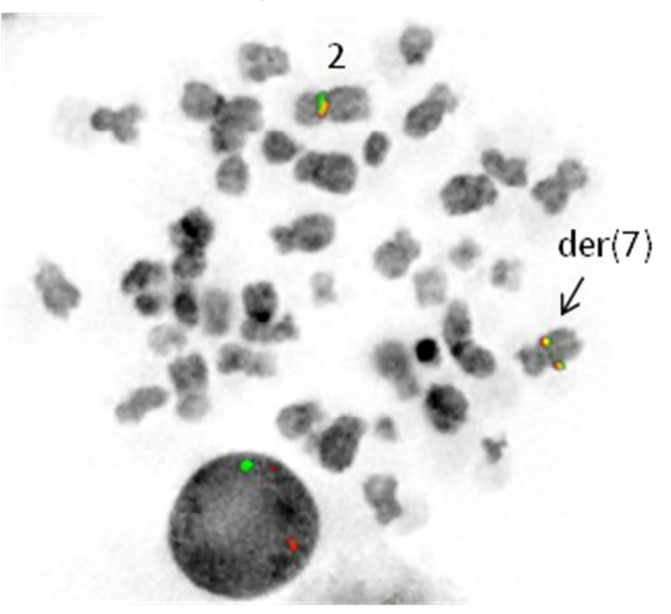

IGK DAKO

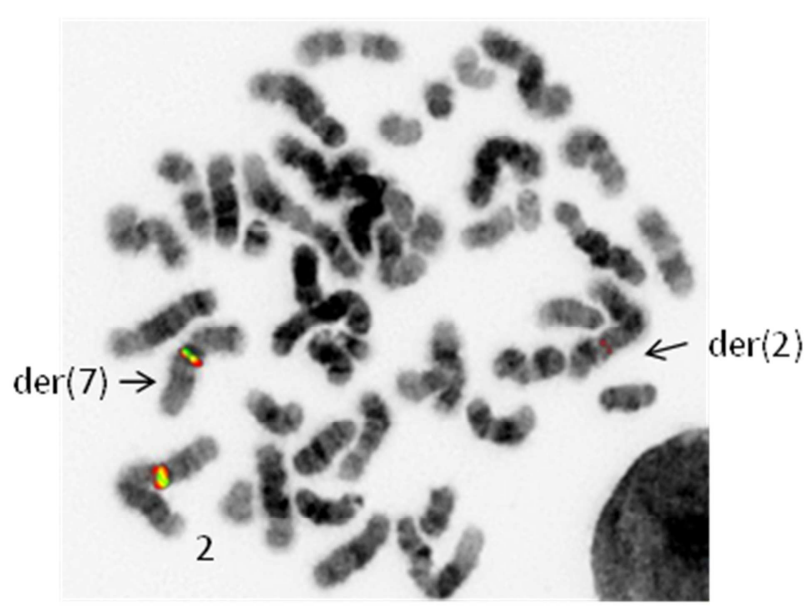

Supplemental Figure S2. Translocation $t(2 ; 7)$ breakpoints in the IGK gene locus. A. Schematic representation of the region covered by the different IGK probes used in the study (approximate probe sizes and gaps between red and green probes are provided), and the distribution of 2 p11 breakpoints. B. FISH images for patient \#8: no splitting signal was seen with the Cytocell IGK probe, which was entirely translocated to the derivative chromosome 7 (left panel), indicating a centromeric $2 \mathrm{p} 11$ breakpoint. With the Dako probe, a fusion signal was seen on the derivative chromosome 7, and a telomeric IGK (red) signal was still seen on the derivative chromosome 2; this suggest that the rearrangement mechanism was complex, with a probable inversion of the $I G K$ locus prior to $t(2 ; 7)$ (right panel). A similar profile was observed in six other patients. 


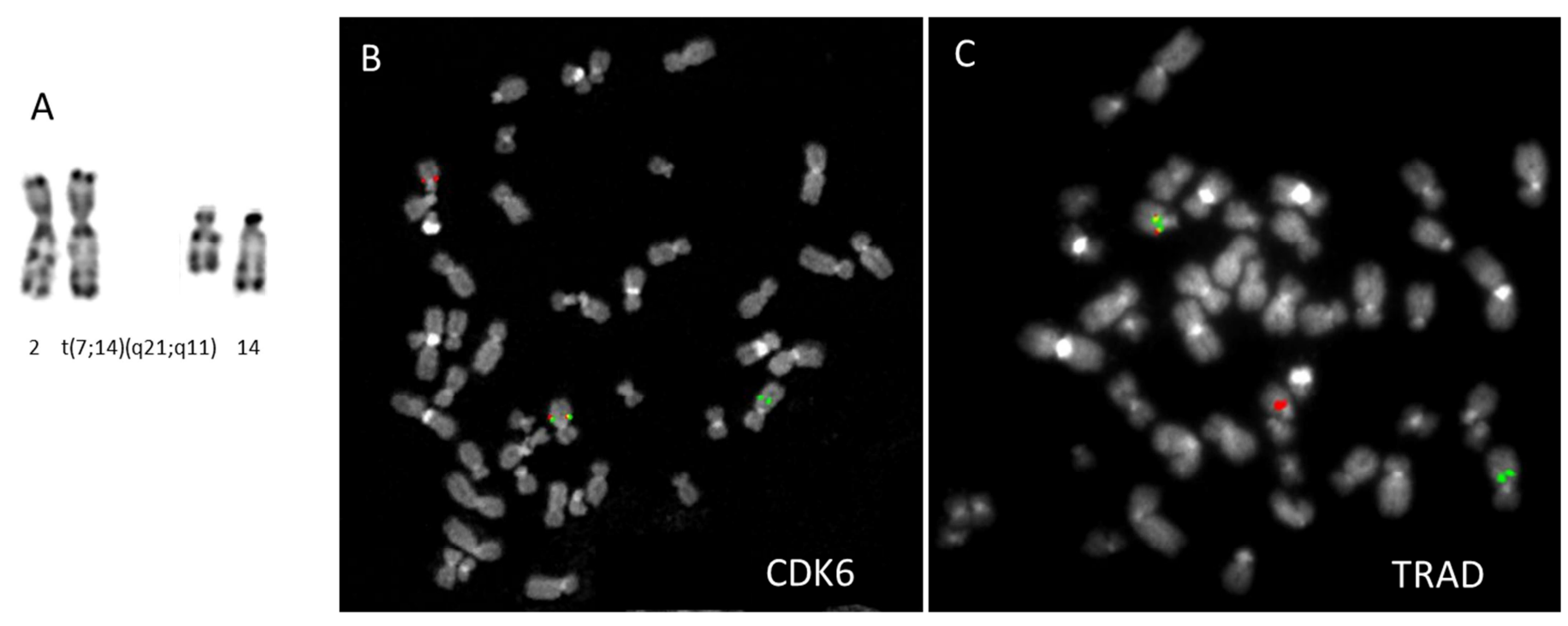

Supplemental Figure S3. Translocation t(7;14)(q21;q11). A. partial R-banded karyotype. B and C. FISH images. B. A representative metaphase from patient \#3, hybridized with the home-made CDK6 break-apart probe (RP11-246N14 labeled with FITC + RP11-90H9 labeled with rhodamine). A red-green signal is seen on the normal chromosome 7, a green signal is present on the derivative chromosome 7 , and a red signal is observed on the derivative chromosome 14. B. A representative metaphase from patient \#3, hybridized with the TRA/TRD (14q11) break-apart probe (Cytocell). A red-green signal is seen on the normal chromosome 14, a red signal is present on the derivative chromosome 14, and a green signal is observed on the derivative chromosome 7. 


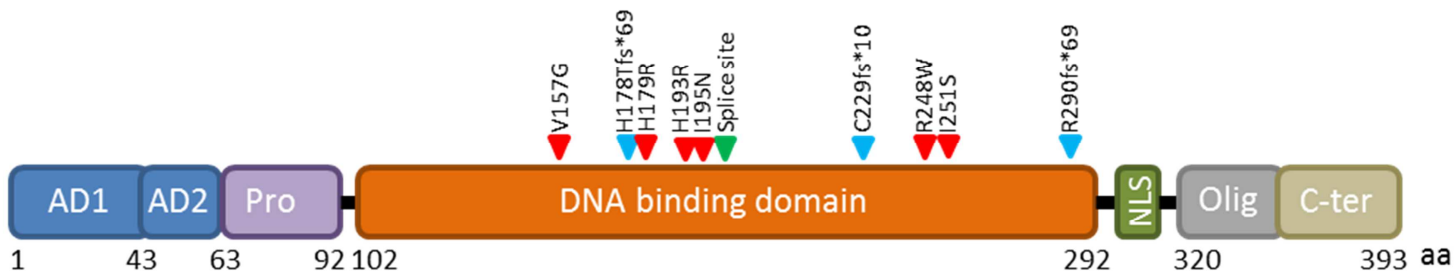

Supplemental Figure S4. TP53 mutations identified in patients with $\mathbf{t}(C D K 6)$. AD1: transactivation domain 1; AD2: transactivation domain 2; Pro: proline-rich domain; NLS: nuclear localization signal; Olig: oligomerization domain; Cter: carboxy terminus domain.

OS at 5 years $(95 \% \mathrm{Cl})$

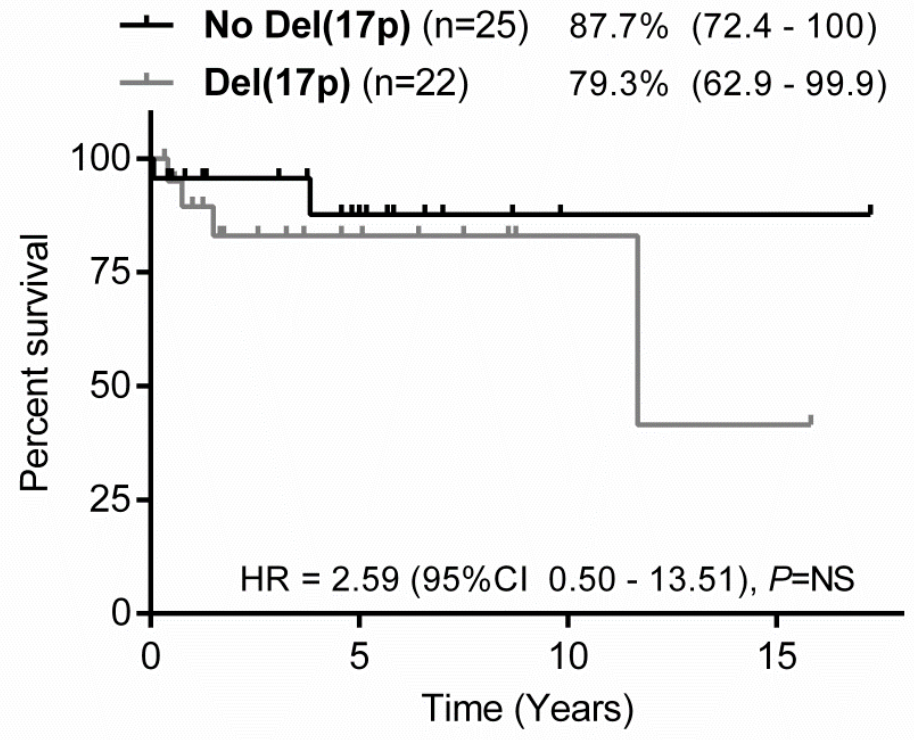

Number at risk

$\begin{array}{rrrr}-25 & 9 & 1 & 1 \\ -22 & 7 & 2 & 1\end{array}$

Supplemental Figure S5. Kaplan-Meier estimates of OS among patients with MZL/SmBL ( $n=47)$, as a function of the presence or absence of the $17 p$ deletion. 
Supplemental Table S1. Clinical, laboratory, cytological and immunophenotyping data for the 57 patients with a $($ (CDK6) translocation

\begin{tabular}{|c|c|c|c|c|c|c|c|c|c|c|c|c|c|c|}
\hline $\begin{array}{c}\text { Patien } \\
\text { t ID }\end{array}$ & Sex & $\begin{array}{l}\text { Splenomegal } \\
\text { y (0: no, 1: } \\
\text { yes) }\end{array}$ & $\begin{array}{c}\text { Lymphadenopath } \\
\text { y (0: no, 1: yes) }\end{array}$ & $\begin{array}{c}\text { Paraprotei } \\
n\end{array}$ & $\begin{array}{c}\text { Initial } \\
\text { diagnosis }\end{array}$ & Histology & $\begin{array}{c}\text { Tissue } \\
\text { examined for } \\
\text { morphologica } \\
\text { I review }\end{array}$ & $\begin{array}{l}\text { Morphological } \\
\text { review } \\
\text { conclusion }\end{array}$ & $\begin{array}{c}\text { Detailed } \\
\text { morphology if } \\
\text { atypical (*or } \\
\text { not reviewed) }\end{array}$ & $\begin{array}{c}\% \\
\text { prolymp } \\
\text { hocytic } \\
\text { cells }\end{array}$ & $\begin{array}{l}\text { Lymphocytosi } \\
\mathrm{s} \text { at diagnosis } \\
\text { (G/L) }\end{array}$ & $\begin{array}{c}\text { CD5 } \\
\text { expression }\end{array}$ & $\begin{array}{c}\text { CD23 } \\
\text { expression }\end{array}$ & $\begin{array}{c}\text { Matutes' } \\
\text { score }\end{array}$ \\
\hline 1 & $M$ & 1 & 0 & - & SMZL & $\begin{array}{c}\text { BM : SMZL } \\
\text { Spleen : SMZL }\end{array}$ & PB & $\overline{S M Z L}$ & & 0 & 3.7 & + & + & 2 \\
\hline 2 & M & 0 & 0 & - & SMZL & $\begin{array}{l}\text { BM : low-grade B- } \\
\text { cell lymphoma }\end{array}$ & PB & SMZL & & 0 & 15.9 & - & - & 0 \\
\hline 3 & M & 0 & 0 & - & SMZL & - & PB & SMZL & & 0 & 5.28 & - & - & 2 \\
\hline 4 & $\mathrm{M}$ & 1 & 0 & $\operatorname{lgM} K$ & SMZL & - & PB & SMZL & & 0 & 11.3 & - & + & 1 \\
\hline 5 & $M$ & 0 & 0 & - & SMZL & - & BM & SMZL & & 0 & 11 & - & NA & NA \\
\hline 6 & $\mathrm{~F}$ & 0 & 0 & - & SMZL & - & BM & atypical SMZL & $\begin{array}{c}\text { numerous } \\
\text { Iymphoplasmoc } \\
\text { ytes }\end{array}$ & 0 & 6.3 & + & + & 3 \\
\hline 7 & M & 0 & 0 & - & SMZL & - & PB & atypical SMZL & $\begin{array}{c}\text { presence of } \\
\text { prolymphocytes }\end{array}$ & 3 & 7.2 & + & + & 2 \\
\hline 8 & $\mathrm{M}$ & 0 & 0 & $\operatorname{lgM~K}$ & SMZL & - & PB & atypical SMZL & $\begin{array}{c}\text { presence of } \\
\text { prolymphocytes }\end{array}$ & 3 & 2.15 & - & - & 1 \\
\hline 9 & $\mathrm{~F}$ & 0 & 1 & $\operatorname{lgM} L$ & SMZL & - & PB & atypical SMZL & $\begin{array}{c}\text { presence of } \\
\text { prolymphocytes }\end{array}$ & 3 & 43.09 & + & - & 1 \\
\hline 10 & $\mathrm{M}$ & 0 & 0 & - & SMZL & - & PB & atypical SMZL & $\begin{array}{c}\text { presence of } \\
\text { prolymphocytes }\end{array}$ & 5 & 10.27 & - & - & 0 \\
\hline 11 & $\mathrm{~F}$ & 1 & 0 & - & SMZL & - & $\mathrm{BM}$ & atypical SMZL & $\begin{array}{c}\text { presence of } \\
\text { prolymphocytes }\end{array}$ & 7 & 29.37 & + & - & 1 \\
\hline 12 & $\mathrm{~F}$ & 1 & 0 & - & SMZL & - & PB & atypical SMZL & $\begin{array}{c}\text { nuclear } \\
\text { irregularity, } \\
\text { numerous } \\
\text { naked nuclei, } \\
\text { presence of } \\
\text { prolymphocytes }\end{array}$ & 9 & 5.8 & + & + & 2 \\
\hline 13 & M & 0 & 0 & $\operatorname{lgM~L}$ & SMZL & - & PB & atypical SMZL & $\begin{array}{c}\text { presence of } \\
\text { prolymphocytes }\end{array}$ & 11 & 3 & - & - & 0 \\
\hline 14 & $\mathrm{~F}$ & 0 & 0 & $\operatorname{lgM} L$ & SMZL & - & PB & atypical SMZL & $\begin{array}{c}\text { presence of } \\
\text { prolymphocytes }\end{array}$ & 16 & 4.25 & - & - & 0 \\
\hline 15 & M & 1 & 0 & $\operatorname{lgM~L}$ & SMZL & - & PB & atypical SMZL & $\begin{array}{l}\text { presence of } \\
\text { prolymphocytes }\end{array}$ & 22 & 7.25 & + & - & 1 \\
\hline 16 & $\mathrm{~F}$ & NA & NA & NA & SZML & - & - & - & & & 2.32 & - & - & 1 \\
\hline 17 & $\mathrm{~F}$ & 1 & 0 & - & SMZL & Spleen : SMZL & - & - & & & 4.4 & - & + & 1 \\
\hline 18 & $\mathrm{M}$ & 0 & 0 & - & SMZL & - & - & - & & & 6.35 & - & - & 0 \\
\hline 19 & $M$ & 1 & 0 & - & SMZL & - & - & - & & & 8.08 & - & NA & NA \\
\hline 20 & $\mathrm{M}$ & 0 & 0 & $\begin{array}{l}\operatorname{lgM~K} \text { and } \\
\operatorname{lgM~L}\end{array}$ & SMZL & $\begin{array}{l}\text { BM : low-grade B- } \\
\text { cell lymphoma }\end{array}$ & - & - & $\begin{array}{l}\text { * some villous } \\
\text { lymphocytes }\end{array}$ & & 9 & - & - & 1 \\
\hline 21 & $\mathrm{~F}$ & NA & NA & NA & SMZL & - & - & - & & & 8.37 & - & - & 1 \\
\hline
\end{tabular}




\begin{tabular}{|c|c|c|c|c|c|c|c|c|c|c|c|c|c|c|}
\hline $\begin{array}{l}\text { Patien } \\
t \text { ID }\end{array}$ & Sex & $\begin{array}{l}\text { Splenomegal } \\
\text { y (0: no, 1: } \\
\text { yes) }\end{array}$ & $\begin{array}{l}\text { Lymphadenopath } \\
\text { y (0: no, 1: yes) }\end{array}$ & $\begin{array}{c}\text { Paraprotei } \\
n\end{array}$ & $\begin{array}{c}\text { Initial } \\
\text { diagnosis }\end{array}$ & Histology & $\begin{array}{c}\text { Tissue } \\
\text { examined for } \\
\text { morphologica } \\
\text { I review }\end{array}$ & $\begin{array}{l}\text { Morphological } \\
\text { review } \\
\text { conclusion }\end{array}$ & $\begin{array}{c}\text { Detailed } \\
\text { morphology if } \\
\text { atypical (*or } \\
\text { not reviewed) }\end{array}$ & $\begin{array}{c}\% \\
\text { prolymp } \\
\text { hocytic } \\
\text { cells }\end{array}$ & $\begin{array}{l}\text { Lymphocytosi } \\
\mathrm{s} \text { at diagnosis } \\
\text { (G/L) }\end{array}$ & $\begin{array}{c}\text { CD5 } \\
\text { expression }\end{array}$ & $\begin{array}{c}\text { CD23 } \\
\text { expression }\end{array}$ & $\begin{array}{c}\text { Matutes' } \\
\text { score }\end{array}$ \\
\hline 22 & $M$ & 1 & 1 & $\overline{N A}$ & $\overline{S M Z L}$ & Spleen : SMZL & - & - & & & 4.488 & + & - & 1 \\
\hline 23 & $\mathrm{~F}$ & 0 & 0 & $\begin{array}{l}\text { IgM K and } \\
\text { IgM L }\end{array}$ & SMZL & & - & - & & & 2.283 & + & - & 1 \\
\hline 24 & $\mathrm{~F}$ & NA & NA & NA & SMZL & BM : SMZL & - & - & & & 8.15 & + & + & 3 \\
\hline 25 & $\mathrm{~F}$ & 0 & 0 & $\operatorname{IgM~K}$ & SMZL & - & - & - & $\begin{array}{l}* \text { presence of } \\
\text { prolymphocytes }\end{array}$ & $\begin{array}{c}\text { not } \\
\text { evaluate } \\
d\end{array}$ & 7.26 & + & - & 1 \\
\hline 26 & $M$ & 0 & 0 & - & BALT & Lung: BALT & PB & typical MZL cells & & 0 & 3.9 & - & + & 1 \\
\hline 27 & M & NA & 1 & NA & NMZL & Lymph node: NMZL & - & - & & & 1 & + & - & 2 \\
\hline 28 & $\mathrm{~F}$ & 0 & 0 & NA & B-PLL & - & PB & atypical SMZL & $\begin{array}{c}\text { presence of } \\
\text { prolymphocytes }\end{array}$ & 48 & 19.75 & - & - & 0 \\
\hline 29 & $\mathrm{~F}$ & NA & NA & NA & B-PLL & - & PB & atypical SMZL & $\begin{array}{l}\text { presence of } \\
\text { prolymphocytes }\end{array}$ & 18 & NA & + & - & NA \\
\hline 30 & $M$ & 0 & 0 & - & B-PLL & - & PB & atypical SMZL & $\begin{array}{l}\text { numerous } \\
\text { lymphoplasmoc } \\
\text { ytes and } \\
\text { presence of } \\
\text { prolymphocytes }\end{array}$ & 12 & 2.26 & - & - & 0 \\
\hline 31 & $M$ & 0 & 0 & - & USBCL & - & PB & SMZL & & 0 & 20.8 & + & - & 1 \\
\hline 32 & $\mathrm{M}$ & 0 & 0 & $\lg G \mathrm{~K}$ & USBCL & - & PB & atypical SMZL & $\begin{array}{c}\text { a majority of } \\
\text { lymphocytes } \\
\text { with a } \\
\text { nucleolus, some } \\
\text { of them being } \\
\text { "true" } \\
\text { prolymphocytes }\end{array}$ & 11 & 6.55 & - & - & 0 \\
\hline 33 & $M$ & 0 & 0 & - & USBCL & - & PB & atypical SMZL & $\begin{array}{l}\text { presence of } \\
\text { prolymphocytes }\end{array}$ & 6 & 8.48 & + & + & 2 \\
\hline 34 & $M$ & 0 & 0 & - & USBCL & $\begin{array}{l}\text { BM : low-grade B- } \\
\text { cell lymphoma }\end{array}$ & PB & atypical SMZL & $\begin{array}{c}\text { numerous } \\
\text { lymphoplasmoc } \\
\text { ytes and } \\
\text { presence of } \\
\text { prolymphocytes }\end{array}$ & 8 & 5.69 & + & + & 2 \\
\hline 35 & $M$ & 0 & 1 & - & USBCL & - & PB & atypical SMZL & $\begin{array}{l}\text { presence of } \\
\text { prolymphocytes }\end{array}$ & 30 & 55.5 & - & - & 1 \\
\hline 36 & $\mathrm{~F}$ & NA & NA & NA & USBCL & - & PB & atypical SMZL & $\begin{array}{l}\text { polymorphic } \\
\text { population with } \\
\text { cells of unequal } \\
\text { size, } \\
\text { heterogeneous } \\
\text { chromatin, } \\
\text { often with a } \\
\text { nucleolus, } \\
\text { presence of } \\
\text { prolymphocytes }\end{array}$ & 8 & 46.4 & - & - & 1 \\
\hline 37 & M & 0 & 0 & - & USBCL & - & - & - & & & 2.41 & + & - & NA \\
\hline
\end{tabular}




\begin{tabular}{|c|c|c|c|c|c|c|c|c|c|c|c|c|c|c|}
\hline $\begin{array}{l}\text { Patien } \\
\text { t ID }\end{array}$ & Sex & $\begin{array}{l}\text { Splenomegal } \\
\text { y (0: no, 1: } \\
\text { yes) }\end{array}$ & $\begin{array}{l}\text { Lymphadenopath } \\
\text { y (0: no, 1: yes) }\end{array}$ & $\begin{array}{c}\text { Paraprotei } \\
n\end{array}$ & $\begin{array}{c}\text { Initial } \\
\text { diagnosis }\end{array}$ & Histology & $\begin{array}{c}\text { Tissue } \\
\text { examined for } \\
\text { morphologica } \\
\text { I review }\end{array}$ & $\begin{array}{l}\text { Morphological } \\
\text { review } \\
\text { conclusion }\end{array}$ & $\begin{array}{c}\text { Detailed } \\
\text { morphology if } \\
\text { atypical (*or } \\
\text { not reviewed) }\end{array}$ & $\begin{array}{c}\% \\
\text { prolymp } \\
\text { hocytic } \\
\text { cells }\end{array}$ & $\begin{array}{c}\text { Lymphocytosi } \\
s \text { at diagnosis } \\
\text { (G/L) }\end{array}$ & $\begin{array}{c}\text { CD5 } \\
\text { expression }\end{array}$ & $\begin{array}{c}\mathrm{CD23} \\
\text { expression }\end{array}$ & $\begin{array}{l}\text { Matutes' } \\
\text { score }\end{array}$ \\
\hline 38 & $M$ & 0 & 0 & $\operatorname{lgM~K}$ & USBCL & $\begin{array}{c}\text { BM : not } \\
\text { informative }\end{array}$ & - & - & & & 2.2 & + & $\mathrm{NA}$ & NA \\
\hline 39 & M & 0 & 0 & - & USBCL & - & - & - & & & 18.96 & + & - & 1 \\
\hline 40 & M & 1 & 0 & - & USBCL & - & - & - & & & 5.5 & + & + & 2 \\
\hline 41 & $\mathrm{~F}$ & 0 & 0 & $\lg G \mathrm{~K}$ & USBCL & $\begin{array}{l}\text { BM : nodular } \\
\text { lymphocytic } \\
\text { infiltration }\end{array}$ & - & - & & & 4.83 & - & - & NA \\
\hline 42 & $\mathrm{M}$ & 0 & 0 & $\operatorname{lgM~K}$ & USBCL & $\begin{array}{l}\text { BM : low-grade B- } \\
\text { cell lymphoma }\end{array}$ & - & - & & & 7.8 & + & - & NA \\
\hline 43 & $\mathrm{~F}$ & 0 & 1 & $\begin{array}{l}\text { yes (not } \\
\text { typed) }\end{array}$ & USBCL & $\begin{array}{l}\text { BM : low-grade B- } \\
\text { cell lymphoma }\end{array}$ & - & - & & & 14.39 & + & - & NA \\
\hline 44 & $\mathrm{~F}$ & 0 & 0 & - & USBCL & $\begin{array}{l}\text { BM : low-grade B- } \\
\text { cell lymphoma }\end{array}$ & - & - & & & 7.7 & + & - & 2 \\
\hline 45 & $\mathrm{~F}$ & 0 & 0 & - & USBCL & - & - & - & & & 35.85 & + & - & 1 \\
\hline 46 & M & 0 & 0 & NA & USBCL & - & - & - & & & 12.99 & + & - & 1 \\
\hline 47 & $\mathrm{~F}$ & 0 & 0 & - & USBCL & - & - & - & & & 19.9 & + & - & 2 \\
\hline 48 & M & NA & NA & NA & CLL & - & BM & CLL & & 0 & 5.74 & + & + & 5 \\
\hline 49 & M & 0 & 0 & NA & CLL & BM: CLL & - & - & & & 11 & + & + & 4 \\
\hline 50 & M & 1 & 0 & NA & CLL & - & PB & CLL & & 0 & 112.4 & + & + & 5 \\
\hline 51 & $\mathrm{~F}$ & NA & NA & NA & CLL & - & BM & CLL & & 0 & 5.05 & + & + & 5 \\
\hline 52 & $M$ & 1 & 1 & - & CLL & - & - & - & & & 33.76 & + & + & 5 \\
\hline 53 & $M$ & 0 & 1 & - & CLL & - & PB & CLL & & 0 & 7.25 & + & + & 4 \\
\hline 54 & $\mathrm{~F}$ & NA & NA & NA & MBL & - & - & - & & & 4.35 & + & + & 4 \\
\hline 55 & M & 0 & 0 & $\operatorname{lgM~K}$ & MBL & - & BM & MBL & & 0 & 2.93 & + & + & 5 \\
\hline 56 & M & 1 & 1 & NA & SLL & Lymph node : SLL & BM & SLL & & 0 & 2.24 & + & + & 5 \\
\hline 57 & M & 1 & 1 & NA & SLL & Lymph node: SLL & - & - & & & 1.96 & + & + & 5 \\
\hline
\end{tabular}

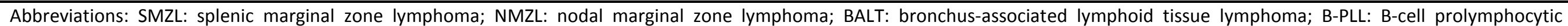

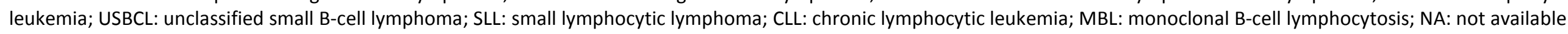


Supplemental Table S2. Cytological findings and karyotypes for 10 cases of SMZL without the $\mathrm{t}(C D K 6)$ translocation. The number of prolymphocytes is quoted as a percentage of total lymphoid cells.

\section{ID Prolymphocytes (\%) Karyotype}

\begin{tabular}{|c|c|c|}
\hline SMZL_1 & 0 & 46,XX,del(7)(q31q35)[6]/46,sl,add(3)(p26),del(8)(p12)[12]/93,sdl1x2,+?del(7)(q31q35),del(17)(p11)x2[1]/46,XX[1] \\
\hline SMZL_2 & 0 & $48, X Y,+3,+18[13] / 46, X Y[3]$ \\
\hline SMZL_3 & 1 & $46, X Y[20]$ \\
\hline SMZL_4 & 1 & 46,XX,del(7)(q2?1q3?1)[2]/46,XX[18] \\
\hline SMZL_5 & 1 & $46, X X[20]$ \\
\hline SMZL_6 & 2 & 46,XX,del(7)(q21q35)[17]/46,XX,t(1;6)(p3?3;q2?5)[2]/46,XX[1] \\
\hline SMZL_7 & 2 & $46, X X, t(2 ; 8 ; 12 ; 15 ; 17)(? ; p 1 ? 2 ; p 1 ? 2 ; q 2 ? 5 ; q 1 ? 2)[18] / 46, X X[2]$ \\
\hline SMZL_8 & 2 & $46, X X[15]$ \\
\hline SMZL_9 & 4 & $46, X Y, t(6 ; 19)(q 26 ; p 1 ? 2), \operatorname{del}(7)(q 3 ? 3 q 335)[1] / 47, s l,+\operatorname{add}(11)(q ? 13)[13] / 48, s d l 1,+12[3] / 46, X Y[3]$ \\
\hline SMZL_10 & 5 & $46, X X, i(17)(q 10)[16]$ \\
\hline
\end{tabular}


Supplemental Table S3. Karyotyping and FISH results in the 57 patients with $\mathrm{t}(C D K 6)$.

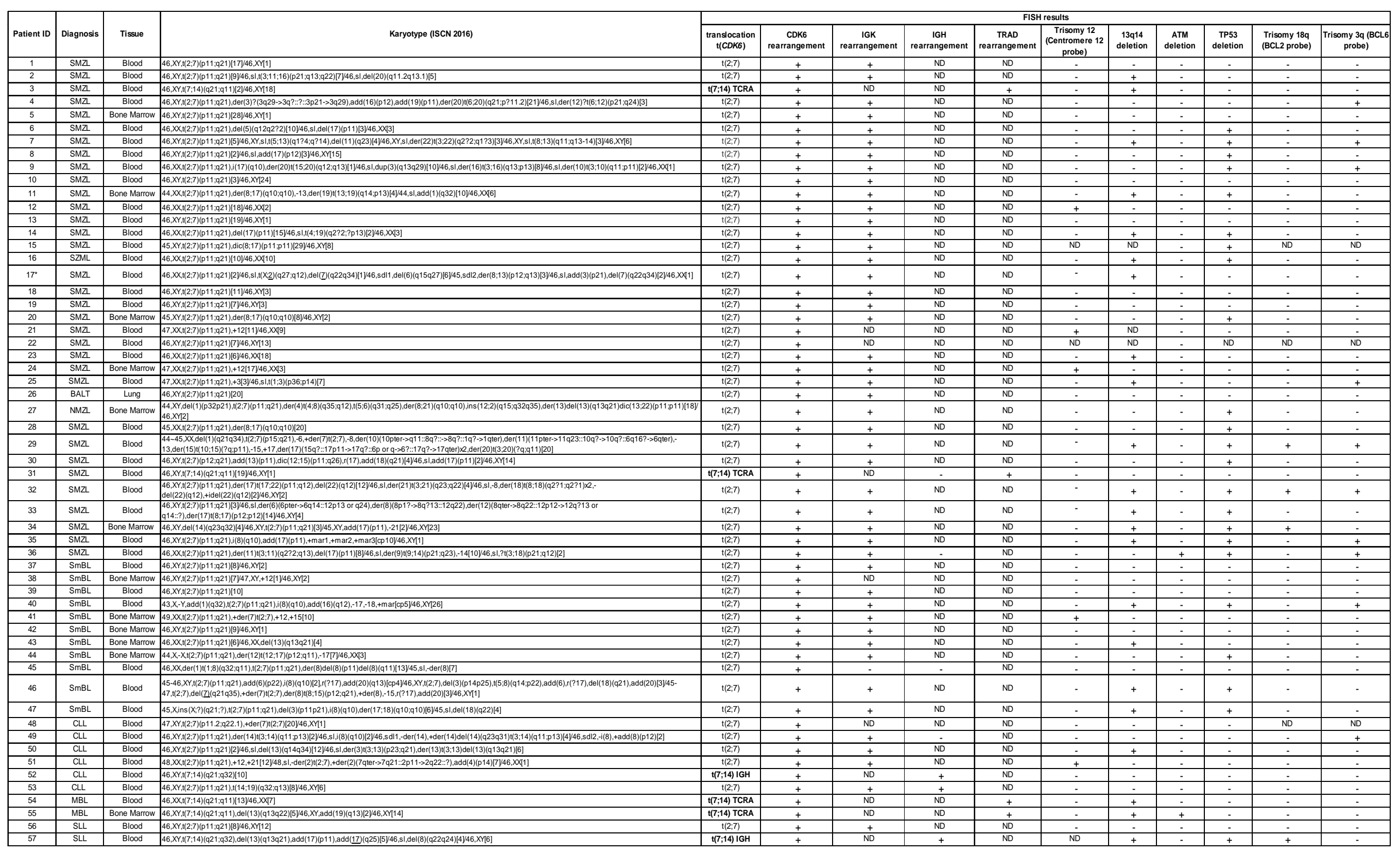

* $t(2 ; 7)(p 11 ; q 21)$ and del(7q) are in two distinct clones (\#17); ND: not done 
Supplemental Table S4. Associations between 17p deletion and the other biological parameters in the whole cohort of patients with $t(C D K 6)$ or in marginal zone lymphomas (MZL) and small B-cell lymphomas (SmBL) cases. Categorical variables were compared using a Fisher's exact test and continuous variables were compared using the Mann-Whitney test (§).

\begin{tabular}{|c|c|c|c|c|c|c|}
\hline \multirow[b]{2}{*}{ Parameter } & \multicolumn{3}{|c|}{ Whole cohort $(n=57)$} & \multicolumn{3}{|c|}{$\mathrm{MZL} / \mathrm{SmBL}(\mathrm{n}=47)$} \\
\hline & $\begin{array}{l}\text { No del(17p) } \\
n=34\end{array}$ & $\begin{array}{c}\operatorname{del}(17 p) \\
n=23\end{array}$ & $P$-value & $\begin{array}{l}\text { No del(17p) } \\
\quad n=25\end{array}$ & $\begin{array}{c}\operatorname{del}(17 p) \\
n=22\end{array}$ & $P$-value \\
\hline Prolymphocytic cells & $4 / 17(24 \%)$ & $14 / 15$ (93\%) & $<0.001$ & $4 / 11(36 \%)$ & $14 / 15(93 \%)$ & 0.003 \\
\hline TP53 mutation & $1 / 21(5 \%)$ & $9 / 15(60 \%)$ & $<0.001$ & $1 / 15(7 \%)$ & $9 / 15(60 \%)$ & 0.005 \\
\hline Complex Karyotype & $10 / 34(29 \%)$ & $18 / 23(78 \%)$ & $<0.001$ & $6 / 25(24 \%)$ & $17 / 22(77 \%)$ & $<0.001$ \\
\hline Highly Complex Karyotype & $4 / 34(12 \%)$ & $14 / 23(61 \%)$ & $<0.001$ & $2 / 25(8 \%)$ & $13 / 22(59 \%)$ & $<0.001$ \\
\hline $\begin{array}{l}\text { Number of chromosomal } \\
\text { abnormalities. median(range) }\end{array}$ & $1(1-7)$ & $5(2-14)$ & $<0.001^{\S}$ & $2.5(1-6)$ & $4(1-14)$ & $<0.001^{\S}$ \\
\hline $13 q 14$ deletion & $9 / 32(28 \%)$ & $13 / 22(59 \%)$ & 0.028 & $6 / 23(26 \%)$ & $12 / 21(57 \%)$ & 0.065 \\
\hline $8 p$ deletion & $3 / 34(9 \%)$ & $11 / 23(48 \%)$ & 0.001 & $2 / 25(8 \%)$ & $11 / 22(50 \%)$ & 0.002 \\
\hline $8 q$ gain & $1 / 34(3 \%)$ & $6 / 23(26 \%)$ & 0.014 & $0 / 25(0 \%)$ & $6 / 22(27 \%)$ & 0.007 \\
\hline
\end{tabular}


Supplemental Table S5. Treatment data for the 57 patients with a $t(C D K 6)$ translocation.

\begin{tabular}{|c|c|c|c|c|c|c|c|c|}
\hline $\begin{array}{l}\text { Patient } \\
\text { ID }\end{array}$ & $\begin{array}{l}\text { Age at diag } \\
\text { (years) }\end{array}$ & Disease & $\begin{array}{c}\text { Number of } \\
\text { lines of } \\
\text { treatment }\end{array}$ & $\begin{array}{l}\text { Time to first } \\
\text { treatment } \\
\text { (months) }\end{array}$ & Treatments & Response & $\begin{array}{l}\text { Follow- } \\
\text { up } \\
\text { (months) }\end{array}$ & Death \\
\hline 1 & 65 & SMZL & 1 & 41 & splenectomy & $\mathrm{CR}$ & 118 & No \\
\hline 2 & 66 & SMZL & 0 & & & & 15 & No \\
\hline 3 & 69 & SMZL & 0 & & & & 10 & No \\
\hline 4 & 69 & SMZL & 0 & & & & 5 & No \\
\hline 5 & 69 & SMZL & 0 & & & & 10 & No \\
\hline 6 & 73 & SMZL & 0 & & & & 105 & No \\
\hline 7 & 72 & SMZL & 0 & & & & 103 & No \\
\hline 8 & 48 & SMZL & 1 & 6 & chlorambucil & $C R$ & 190 & No \\
\hline 9 & 74 & SMZL & 1 & 10 & R-idelalisib & $C R$ & 31 & No \\
\hline 10 & 67 & SMZL & 0 & & & & 207 & No \\
\hline 11 & 78 & SMZL & 3 & 1 & $\begin{array}{c}\text { R-CVP } \\
\text { R-bendamustine } \\
\text { idelalisib }\end{array}$ & $\begin{array}{c}\text { Failure } \\
\text { Failure } \\
\text { PR }\end{array}$ & 21 & No \\
\hline 12 & 61 & SMZL & 1 & 26 & R-bendamustine & Not available & 46 & Yes \\
\hline 13 & 65 & SMZL & 1 & 41 & $\mathrm{RDC}$ & Treatment in progress & 79 & No \\
\hline 14 & 62 & SMZL & 0 & & & & 90 & No \\
\hline 15 & 86 & SMZL & 0 & & & & 18 & Yes \\
\hline 16 & 90 & SZML & 0 & & & & 55 & No \\
\hline 17 & 78 & SMZL & 1 & 48 & splenectomy & $\mathrm{CR}$ & 84 & No \\
\hline 18 & 70 & SMZL & 1 & 39 & R-chlorambucil & PR & 45 & No \\
\hline 19 & 35 & SMZL & 0 & & & & 1 & No \\
\hline 20 & 66 & SMZL & 0 & & & & 12 & No \\
\hline 21 & 85 & SMZL & 0 & & & & 16 & No \\
\hline 22 & 50 & SMZL & 1 & 53 & splenectomy & $\mathrm{CR}$ & 60 & No \\
\hline 23 & 77 & SMZL & 0 & & & & 0 & No \\
\hline 24 & 76 & SMZL & 1 & 42 & R-chlorambucil & Not available & 55 & No \\
\hline 25 & 51 & SMZL & 1 & 56 & RFC & Treatment in progress & 58 & No \\
\hline 26 & 71 & BALT & 0 & & & & 1 & Yes \\
\hline 27 & 66 & NMZL & 1 & 0 & $\mathrm{R}-\mathrm{CHOP}$ & $\mathrm{CR}$ & 15 & No \\
\hline 28 & 78 & SMZL & 1 & 7 & R-idelalisib & $\mathrm{CR}$ & 44 & No \\
\hline 29 & 65 & SMZL & 1 & 0 & R-CHOP & Not available & 4 & No \\
\hline 30 & 85 & SMZL & 0 & & & & 7 & No \\
\hline 31 & 60 & SMZL & 0 & & & & 62 & No \\
\hline 32 & 63 & SMZL & 5 & 73 & $\begin{array}{c}\text { chlorambucil } \\
\text { splenectomy } \\
\text { R-bendamustine } \\
\text { R ESHA carbo } \\
\text { R-CHOP }\end{array}$ & $\begin{array}{c}\text { PR } \\
\text { CR } \\
\text { Progression } \\
\text { Failure } \\
\text { Failure }\end{array}$ & 140 & Yes \\
\hline 33 & 76 & SMZL & 0 & & & & 7 & No \\
\hline 34 & 74 & SMZL & 0 & & & & 61 & No \\
\hline 35 & 79 & SMZL & 1 & 27 & R-bendamustine & $\mathrm{CR}$ & 39 & No \\
\hline 36 & 86 & SMZL & 0 & & & & 0 & Yes \\
\hline
\end{tabular}




\begin{tabular}{|c|c|c|c|c|c|c|c|c|}
\hline $\begin{array}{l}\text { Patient } \\
\text { ID }\end{array}$ & $\begin{array}{l}\text { Age at diag } \\
\text { (years) }\end{array}$ & Disease & $\begin{array}{c}\text { Number of } \\
\text { lines of } \\
\text { treatment }\end{array}$ & $\begin{array}{c}\text { Time to first } \\
\text { treatment } \\
\text { (months) }\end{array}$ & Treatments & Response & $\begin{array}{l}\text { Follow- } \\
\text { up } \\
\text { (months) }\end{array}$ & Death \\
\hline 37 & 59 & SmBL & 0 & & & & 10 & No \\
\hline 38 & 65 & SmBL & 1 & 58 & R-bendamustine & PR & 68 & No \\
\hline 39 & 46 & $\mathrm{SmBL}$ & 0 & & & & 0 & No \\
\hline 40 & 54 & $\mathrm{SmBL}$ & 2 & 3 & $\begin{array}{c}\text { R-CHOP } \\
\text { R-COPADEM }\end{array}$ & $\begin{array}{l}\text { Failure } \\
\text { Failure }\end{array}$ & 5 & Yes \\
\hline 41 & 79 & SmBL & 0 & & & & 70 & No \\
\hline 42 & 55 & $\mathrm{SmBL}$ & 0 & & & & 6 & No \\
\hline 43 & 64 & SmBL & 0 & & & & 37 & No \\
\hline 44 & 76 & SmBL & 0 & & & & 20 & No \\
\hline 45 & 72 & $\mathrm{SmBL}$ & 4 & 50 & $\begin{array}{l}\text { R-fludarabine } \\
\text { chlorambucil } \\
\text { chlorambucil } \\
\text { fludarabine }\end{array}$ & $\begin{array}{c}\text { CR } \\
\text { Progression } \\
\text { Progression } \\
\text { PR }\end{array}$ & 104 & No \\
\hline 46 & 81 & SmBL & 0 & & & & 9 & Yes \\
\hline 47 & 68 & $\mathrm{SmBL}$ & 2 & 18 & $\begin{array}{l}\text { Mabcampath } \\
\text { ibrutinib }\end{array}$ & $\begin{array}{c}\text { PR } \\
\text { Treatment in progress }\end{array}$ & 77 & $\begin{array}{l}\text { No } \\
\text { No }\end{array}$ \\
\hline 48 & 58 & CLL & 4 & 44 & $\begin{array}{c}\text { R-CHOP } \\
\text { RFC } \\
\text { R-bendamustine } \\
\text { ibrutinib }\end{array}$ & $\begin{array}{l}\mathrm{CR} \\
\mathrm{CR} \\
\mathrm{CR} \\
\mathrm{CR}\end{array}$ & 159 & $\begin{array}{l}\text { No } \\
\text { No } \\
\text { No } \\
\text { No }\end{array}$ \\
\hline 49 & 73 & CLL & 2 & 58 & $\begin{array}{l}\text { bendamustine } \\
\text { chlorambucil }\end{array}$ & $\begin{array}{c}\text { Progression } \\
\text { Not evaluated } \\
\text { (toxicity) }\end{array}$ & 96 & Yes \\
\hline 50 & 66 & CLL & 2 & 11 & $\begin{array}{c}\text { RFC } \\
\text { R-idelalisib }\end{array}$ & $\begin{array}{l}\mathrm{CR} \\
\mathrm{CR}\end{array}$ & 75 & No \\
\hline 51 & 55 & CLL & 1 & 114 & RFC & $C R$ & 137 & No \\
\hline 52 & 51 & CLL & 0 & & & & 10 & No \\
\hline 53 & 86 & CLL & 3 & 2 & $\begin{array}{c}\text { R-chlorambucil } \\
\text { R-CHOP } \\
\text { GEMOX }\end{array}$ & $\begin{array}{c}\text { CR } \\
\text { Failure } \\
\text { Failure }\end{array}$ & 34 & Yes \\
\hline 54 & 76 & MBL & 0 & & & & 1 & No \\
\hline 55 & 87 & MBL & 1 & 3 & chlorambucil & Not available & 23 & No \\
\hline 56 & 51 & SLL & 1 & 3 & RFC & $\mathrm{CR}$ & 54 & No \\
\hline 57 & 70 & SLL & 4 & 1 & $\begin{array}{l}\text { R-idelalisib } \\
\text { R-CHOP } \\
\text { R-GEMOX } \\
\text { ibrutinib }\end{array}$ & $\begin{array}{c}\text { Failure } \\
\text { Progression } \\
\text { PR } \\
\text { Progression }\end{array}$ & 11 & Yes \\
\hline
\end{tabular}

Abbreviations: R: rituximab; F: fludarabine; C: cyclophosphamide; CHOP: cyclophosphamide + hydroxydoxorubicin + vincristine + prednisone; CVP: cyclophosphamide + vincristine + prednisone: GEMOX: gemcitabine + oxaliplatine ; COPADEM: cyclophosphamide + vincristine + doxorubicin + prednisone + methotrexate CR: complete remission; PR: partial remission 
Supplemental Table S6. A univariate analysis of overall survival in the MZL/SmBL subgroup, according to the Kaplan-Meier method.

\begin{tabular}{|ll|cccc|}
\cline { 3 - 6 } \multicolumn{1}{l|}{} & \multicolumn{5}{c|}{ MZL/SmBL (n=47) } \\
\hline Parameter & $\begin{array}{c}\text { OS at 5 } \\
\text { years (\%) }\end{array}$ & HR & 95\%Cl & P-value \\
\hline CD5 expression & negative & 90.5 & 1.51 & $0.28-8.25$ & 0.633 \\
& positive & 78.4 & & & \\
Prolymphocytic cells & no & 88.9 & 1.08 & $0.11-10.52$ & 0.829 \\
& yes & 75.7 & & & \\
del(17p) & no & 87.7 & 2.59 & $0.50-13.51$ & 0.243 \\
& yes & 79.3 & & & \\
TP53 mutated & no & 92.3 & 3.33 & $0.26-41.97$ & 0.333 \\
& yes & 90.0 & & & \\
TP53 disrupted & no & 90.0 & 3.43 & $0.40-29.70$ & 0.426 \\
(mut and/or del) & yes & 80.9 & & & \\
\hline
\end{tabular}

HR: hazard ratio; $\mathrm{Cl}$ : confidence interval 
Supplemental Table S7. Comparison of the frequencies of genetic aberrations and CD5 expression in cases of $t(C D K 6)+$ marginal zone lymphoma (MZL) vs. small B-cell lymphoma (SmBL) in the current study, and literature data on splenic MZL (SMZL).

\begin{tabular}{|c|c|c|c|c|c|c|}
\hline & $\mathrm{t}(C D K 6)+\mathrm{MZL} / \mathrm{SmBL}$ & & & $\underline{\text { SMZL }}$ & & \\
\hline Genetic abnormality & $\begin{array}{l}\text { Current study, }(n=47) \\
\text { frequence }(\%)\end{array}$ & $\begin{array}{l}\text { Salido et al. }{ }^{1} \\
\quad(n=330) \\
\text { frequence (\%) }\end{array}$ & $\begin{array}{l}\text { Rossi et al. }^{2} \\
(n=117) \\
\text { frequence }(\%)\end{array}$ & $\begin{array}{l}\text { Parry, et al. }{ }^{3} \\
\quad(n=175) \\
\text { frequence (\%) }\end{array}$ & $\begin{array}{c}\text { Bikos et al. }^{4} \\
\quad(n=337) \\
\text { frequence }(\%)\end{array}$ & $\begin{array}{l}\text { Oquendo et al. } \\
\qquad(n=475) \\
\text { frequence }(\%)\end{array}$ \\
\hline Complex karyotype & 49 & 53 & & & & \\
\hline $\operatorname{del}(17 p)$ & 47 & 18 & & 33 & & \\
\hline 7q deletion & 2 & 39 & & 19 & & \\
\hline Trisomy 3/3q & 19 & 25 & & & & \\
\hline Trisomy $18 / 18 q$ & 6 & 10 & & & & \\
\hline Trisomy $12 / 12 q$ & 11 & 8 & & & & \\
\hline $\operatorname{del}(8 p)$ & 28 & 4 & & & & \\
\hline $8 q$ gain & 13 & 2 & & & & \\
\hline $14 q$ deletion & 6 & 3 & & & & \\
\hline 14q32 translocation* & 0 & 12 & & & & \\
\hline TP53 mutation & 33 & & 14.5 & 16 & & 15 \\
\hline NOTCH2 ex34 mutation & 0 & & 21.3 & 10 & & 20 \\
\hline MYD88 L265P mutation & 16 & & 5.1 & 4 & & 5 \\
\hline IGHV mutated** & 86 & 86 & & & 86.7 & \\
\hline IGHV1-02*04 & 0 & & & 13 & 23 & \\
\hline CD5 expression & 55 & 25 & & 27 & & \\
\hline
\end{tabular}

1. Salido M, Baro C, Oscier D, et al. Cytogenetic aberrations and their prognostic value in a series of 330 splenic marginal zone B-cell lymphomas: a multicenter study of the Splenic B-Cell Lymphoma Group. Blood 2010;116:1479-1488

2. Rossi $D$, Trifonov V, Fangazio M, et al. The coding genome of splenic marginal zone lymphoma: activation of NOTCH2 and other pathways regulating marginal zone development. The Journal of experimental medicine 2012;209:1537-1551

3. Parry M, Rose-Zerilli MJ, Ljungstrom V, et al. Genetics and Prognostication in Splenic Marginal Zone Lymphoma: Revelations from Deep Sequencing. Clinical cancer research : an official journal of the American Association for Cancer Research 2015;21:4174-4183.

4. Bikos V, Darzentas N, Hadzidimitriou A, et al. Over $30 \%$ of patients with splenic marginal zone lymphoma express the same immunoglobulin heavy variable gene: ontogenetic implications. Leukemia 2012;26:1638-1646.

5. Jaramillo Oquendo C, Parker H, Oscier D, et al. Systematic Review of Somatic Mutations in Splenic Marginal Zone Lymphoma. Scientific reports 2019;9:10444 